PALEO

Revue d'archéologie préhistorique

30-1 | 2019

Varia

\title{
Personal Ornaments in the Mid Upper Palaeolithic East of the Carpathians
}

Parures du Paléolithique supérieur moyen à l'est des Carpates

Marin Cârciumaru, Elena-Cristina NiŢu, Theodor Obadă, Ovidiu Cîrstina, Serghei Covalenco, Florin Ionut Lupu, Marian Leu and Adrian Nicolae

\section{(2) OpenEdition \\ 12 Journals}

Electronic version

URL: http://journals.openedition.org/paleo/4446

DOI: $10.4000 /$ paleo.4446

ISSN: 2101-0420

Publisher

SAMRA

Printed version

Date of publication: 30 December 2019

Number of pages: 80-97

ISSN: $1145-3370$

\section{Electronic reference}

Marin Cârciumaru, Elena-Cristina Niţu, Theodor Obadă, Ovidiu Cîrstina, Serghei Covalenco, Florin lonuţ Lupu, Marian Leu and Adrian Nicolae, " Personal Ornaments in the Mid Upper Palaeolithic East of the Carpathians », PALEO [Online], 30-1 | 2019, Online since 29 May 2020, connection on 07 July 2020 URL : http://journals.openedition.org/paleo/4446 ; DOI : https://doi.org/10.4000/paleo.4446

\section{(c) (†)}

PALEO est mis à disposition selon les termes de la licence Creative Commons Attribution - Pas d'Utilisation Commerciale - Pas de Modification 4.0 International. 
Mid Upper Palaeolithic personal ornaments found in sites located between Carpathians and the Dniester river, more precisely in the settlements of Poiana Cireșului-Piatra Neamt, Mitoc-Malu Galben, the Brînzeni cave, the Duruitoarea Veche cave, Cosăuți, Climăuți II and Molodova V, have been analysed. The ornaments come from occupations falling in between 26-27 ka uncal. BP and $17 \mathrm{ka}$ uncal. BP. The study of ornaments of this homogeneous and restricted area allow us to discuss the existence of some differences in the technical and stylistic choices of these symbolic productions. The article also serves a documentary purpose, as far as all ornaments discovered east of the Prut, in the Republic of Moldova,

Marin Cârciumarua, Elena-Cristina Nițua, Theodor Obadăb', Ovidiu Cîrstinaa, Serghei Covalencoc, Florin Ionut Lupua, Marian Leua, Adrian Nicolae

a. Princely Court" National Museum Târgovişte, Museum of Human Evolution and Technology in Palaeolithic, 7 Justiţiei Street, Târgovişte 130017,

Dâmboviţa County, Romania - mcarciumaru@yahoo.com

elenacristinanitu@yahoo.com; ovidiu_cirstina@yahoo.com florinionut_lupu@yahoo.com; leumarian1993@gmail.com nicoladrian@gmail.com

b. Institute of Zoology, Republic of Moldova, 1 Academiei Street, Chisinău, theodorobada@gmail.com

c. Institute of Cultural Heritage, Republic of Moldova, 1 Ștefan cel Mare Street, Chisinău, covalenco@bk.ru

PALE0 30 | t. 1

DÉCEMBRE 2019

PAGES 80 À 97

KEY-WORDS Gravettian, Epigravettian, personal ornaments, Eastern Carpathians, symbolic behavior. 
Parures du Paléolithique supérieur moyen à l'est

des Carpates.

Cet article traite des parures du Paléolithique supérieur moyen découvertes dans les sites situés entre l'est des Carpates Orientales jusqu'au Dniestr, plus précisément les artéfacts découverts à Poiana Cireşului - Piatra-Neamţ, Mitoc-Malu Galben, dans les grottes de Brînzeni et de Duruitoarea Veche, à Cosăuţi, Climăuţi II et Molodova V. Les parures proviennent d'habitations datées entre 26-27 ka uncal. BP et $17 \mathrm{ka}$ uncal. BP. L'étude des objets de parure de cet espace géographique homogène et restreint nous permet de discuter de certaines différences dans les choix techniques et stylistiques dont témoignent ces productions symboliques. Cet article répond aussi à un objectif documentaire, dans la mesure où les parures découvertes à l'est du Prut, en République de Moldavie, ne sont connues que par le biais de certains dessins publiés qui, du reste, ne sont pas toujours suffisamment précis et informatifs.

\section{INTRODUCTION}

Personal ornaments probably played an essential role in the individualization of ethnic groups and the awareness of belonging to a certain group whose cohesion was influenced by their significance and message. Thus, these objects are archaeological documents of primary importance to study the first symbolic manifestations/the origin of symbolic thinking. Therefore, it is not by chance that these ornaments are quite common in Palaeolithic sites, often standing out through the variety of raw material, such as ivory, antler, bone, shells or the most diverse rocks. The way they were used was equally diverse, as they were applied to garments or accessories, worn as necklaces, bracelets etc. The aspect or colour of blanks must also have a deep symbolic connotation. It may be said that, beside the undeniable aesthetic value, the ornament was a way of differentiating a group or the status of each person in that particular group and thus could be passed on to future generations with all its symbolic value given by its creators or could be used for exchange networks. Ornaments were very often part of the burial inventory, hence their role continued after the individual's death (Kuhn and Stiner 2006; Paillet 2014, 2018; Taborin 1993a, 1996; Vanhaeren 2010; Vanhaeren and d'Errico 2003).

Given the importance and role of personal ornaments, we have deemed it useful to review older or more recent finds in the territory stretching between the eastern slope of the Carpathians and the Dniester River, in settlements attributed to the Gravettian lato sensu or some cultural levels contemporary with it. Although the number of sites with such finds is rather small, the variety of the type of adornments particularises some of these settlements and even individualises certain regions (tabl.1). The chosen settlements are located on the valleys of three rivers, as follows: Poiana Ciresului-Piatra Neamt on the Bistrita valley; Mitoc-Malu Galben, Brînzeni and Duruitoarea Veche cave on the Prut river valley; Cosăuți, Climăuți and Molodova $V$ on the Dniester valley (fig. 1). The study of ornaments in this area was prompted, first, by the fact that some of them reflect different technical and stylistic choices and that all those discovered east of the Prut, in the Republic of Moldova, are only known through the publication of some drawings (Abramova 1995; Borziac, Chirica 1996; Borziac et al. 1992, 1998, 2007; Chirica, Borziac 1995; Noiret 2009) which have not always been revealing enough, especially in western scientific community. In view of this situation, we have considered it necessary to publish the first photographs of most of the ornaments discovered east of the Prut, alongside the description of each item. We are hopeful that this study will raise awareness of the importance of these art objects that unfortunately have not yet been the subject of accurate techno-typological analyses carried out with the most adequate modern microscopic means as compared to those found in Romania. Due to the uneven scientific research and exploitation of ornaments between the Carpathians and the Dniester, we shall attempt to identify the possible regional particularities of the distribution of some of them, as well as their implications in defining the overall cultural aspects. 


\begin{tabular}{|c|c|c|c|c|c|c|c|}
\hline & $\begin{array}{c}\text { Poiana } \\
\text { Cireșului- } \\
\text { Piatra Neamt }\end{array}$ & $\begin{array}{c}\text { Mitoc- } \\
\text { Malul } \\
\text { Galben }\end{array}$ & $\begin{array}{l}\text { Brînzeni } \\
\text { Cave }\end{array}$ & $\begin{array}{l}\text { Duruitoarea } \\
\text { Veche Cave }\end{array}$ & Cosăuți & Climăuți & $\begin{array}{c}\text { Molodova } \\
\text { V }\end{array}$ \\
\hline $\begin{array}{c}\text { endants and } \\
\text { beads made of } \\
\text { stone }\end{array}$ & 2 & 1 & & & 3 & & \\
\hline $\begin{array}{l}\text { Ornaments on } \\
\text { animal teeth }\end{array}$ & 5 & & 1 & 2 & 7 & & 1 \\
\hline erforated shells & 57 & & & & 2 & 24 & $3(?)$ \\
\hline Bone pendants & & 1 & & 1 & & & \\
\hline Ivory pendants & & & 1 & 1 & & & 1 \\
\hline $\begin{array}{c}\text { Belemnite } \\
\text { pendant }\end{array}$ & & & & 1 & & & \\
\hline Ivory bracelets & & & & & 6 & 4 & \\
\hline erforated bones & & & & 1 & & 1 & \\
\hline Amber pendant & & & & & 1 & & \\
\hline Fossil coral beads & & & & & 2 & & \\
\hline $\begin{array}{c}\text { Tubular bone } \\
\text { beads }\end{array}$ & & & & & & 5 & \\
\hline Total & 64 & 2 & 2 & 6 & 21 & 34 & 5 \\
\hline
\end{tabular}

- TABLEAU 1 -

The types of personal ornaments discovered in the Mid Upper Paleolithic sites located East of the Carpathians.

Les types de parures découvertes dans les sites du Paléolithique supérieur moyen à l'est des Carpates.

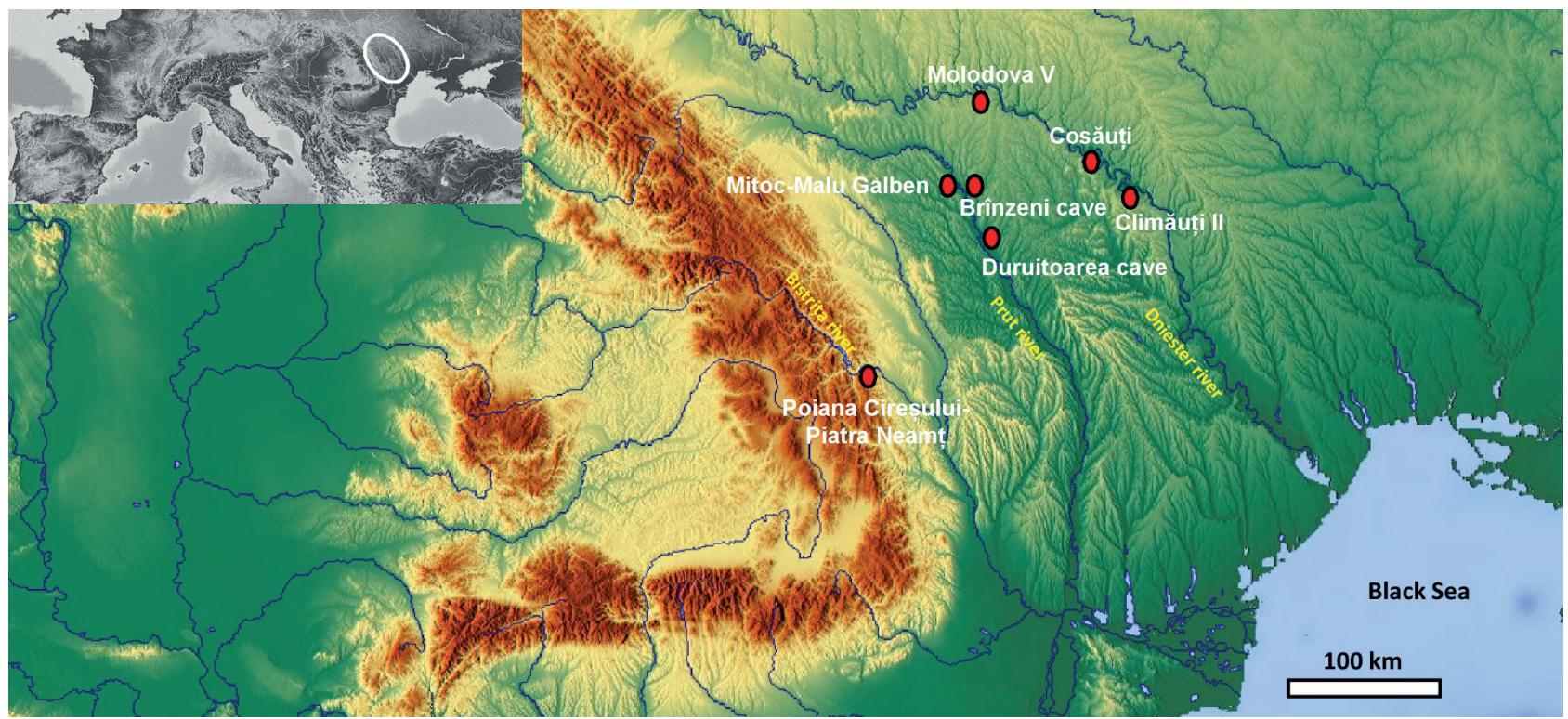

- FIGURE 1 -

The sites between the Carpathians and the Dniester in which Mid Upper Paleolithic ornaments have been found.

\section{1 | METHODS}

All personal ornaments from the Poiana Ciresului-Piatra Neamt, site were studied with microscopy. An STM 8-T stereomicroscope equipped with a Nikon camera and a Keyence VHX-600 (x 200 magnification) optical digital microscope was used. The results of analyses, along with microphotographs, are published in extensive studies (Cârciumaru amd Nițu, 2018; Cârciumaru et al., 2018; Nițu et al., 2019). In the case of Mitoc-Malu Galben and
Localisation des sites situés entre les Carpates et le Dniestr, dans lesquels ont été découverts des objets de parure datant du Paléolithique supérieur moven.

Molodova $V$ sites, the observations are taken from the published bibliography (Abramova, 1995; Cernîș, 1987; Chirica, 1982; Beldiman, 2004). The materials originating from the Brînzeni cave, the Duruitoarea Veche cave, Cosăuți, Climăuți II and Molodova V sites have not benefited from microscopic analyses, therefore our observations are only macroscopic. 


\section{2 | POIANA CIRESULUI-PIATRA NEAMT THE KEY PALAEOLITHIC SITE ON THE BISTRIȚA VALLEY}

\section{1 | Site background}

The Palaeolithic settlement of Poiana Ciresului is located in north-eastern Romania, on the right side of the Bistrița river, at the confluence with the Doamna brook (46055' North latitude and 26019' East longitude). Administratively, the settlement is part of the city of Piatra Neamt, Neamt, County. The settlement deposit has been investigated in several stages, but systematic archaeological excavations were carried out since 1998 (Cârciumaru et al. 2002-2003, 2006; 2007; 2007-2008; 2010; 2012), showing the exceptional potential of this settlement for defining the cultural aspects of the Upper Paleolithic in the Bistrița valley and Eastern Carpathians (Cârciumaru, Nițu 2018; Cârciumaru et al. 2016; 2018; Nițu et al. 2019). The following cultural sequence has been identified:

- layer 1, Epigravettian (over 1,500 lithic items), located in the upper part of the deposit, around $50 \mathrm{~cm}$ depth;

- layer 2, Gravettian (numbered Gravettian I), which is found between 170 and $210 \mathrm{~cm}$ depth and has been dated several times, being placed between 19,320 \pm 80 B.P. (OxA$36785)(23,538-22,992$ cal. B.P.) and 20,154 \pm 97 B.P. (ER 12,163) (24,096 cal. B.P.);

- layer 3, Gravettian (numbered Gravettian II), lying between 290 and $310 \mathrm{~cm}$, with dates between 23,420 \pm 310 B.P. (OxA-X-2762) and 25,135 \pm 150 B.P. (Beta Analytic 244.072); - layer 4, Gravettian (numbered Gravettian III), located between 375 and $415 \mathrm{~cm}$, dated to between 25,390 \pm 140 B.P. (Beta Analytic 244.073) (29,895-29,030 cal. B.P.) and 27,321 \pm 234 B.P. (ER 11,859) (31,969 cal. P.B.);

- layer 5, Early Upper Palaeolithic level, located between

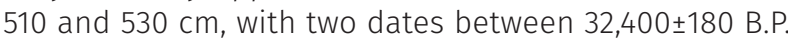
(Beta 507,489) $(36,750-35,850$ cal. B.P.) and $32,630 \pm 190$ B.P. (37,250-36,077 cal. B.P.);

- layer 6, Early Upper Palaeolithic level, $555 \mathrm{~cm}$ deep, dated to $37,550 \pm 360$ B.P. $(42,475-41,417$ cal. B.P.).

\section{2 | Ornaments description}

The Poiana Cireșului-Piatra Neamt settlement has provided almost all the art objects $(94 \%, \mathrm{~N}=82)$ and over $85 \%(\mathrm{~N}=64)$ of the ornaments found in the Romanian Mid Upper Palaeolithic (Cârciumaru, Nițu 2018 ; Cârciumaru et al. 2018 ; Nițu et al. 2019). Most of them were discovered in archaeological campaigns carried out in the last 6 years (2013-2018).

The ornaments of the first Gravettian layer (circa $20 \mathrm{ka}$ uncal B.P.) are characterised by the diversity of shapes, of raw materials used and of blanks, and in some cases it is difficult to find analogies in the Gravettian or Epigravettian in Europe. Five pendants, one made of stone and four made of animal teeth (wolf, fox, deer), a stone bead and perforated shells of the Tritia sp., Dentalium and Potamides bicostatus stand out (fig. 2).

\subsection{1 | Pendants and beads made of stones}

The engraved stone pendant is one of the few such finds in the Gravettian (fig. $2, n^{\circ} 1$ ), as most of the items are perforated slabs without engravings. The pendant was made of a relatively soft rock, a polymictic siltite, with a slightly greenish tint (Cârciumaru et al. 2016). The pendant is oval, with a convex to slightly concave profile. It has a unique perforation intended for hanging, which is located at one of its extremities. It is engraved on both sides and most of the pendant's outline is marked with a total of 23 parallel and linear incisions (notches), arranged, by an overwhelming majority, roughly $3 \mathrm{~mm}$ apart. The engravings on the upper face consist of four rows of incised, relatively parallel lines, realised by the grooving technique. The irregular incisions seem to ensue from the particular morphology of the lithic tool used, most probably a burin; the reverse is decorated with two relatively parallel incisions which are quite firmly traced, without hesitation (for more details see Cârciumaru et al. 2016). The bead made of calcareous marl is the first of this kind from the Palaeolithic in Romania (fig. $2, n^{\circ} 2$ ). Its shape is not perfectly round, but rather oval, as resulted from the ratio of the two diameters. The hole is located roughly in the middle of the surface. It is biconical, tilted relative to the bead plane, because of the attempt to correlate the perforation from the two directions. Post-depositional actions and processes transformed the bead surface. The two surfaces still have portions that were polished, which are actually the only ones that preserve vague traces of ochre (Cârciumaru et al., 2018).

\subsubsection{Ornaments on animal teeth}

Of the perforated teeth, the wolf canine best preserves the wearing traces. It was found during the 2002 campaign (fig. 2, n 3). (Cârciumaru et al. 2012; Cârciumaru, Nițu 2018; Cârciumaru et al. 2018). The perforation was made from one direction. In order to obtain the perforation, one of the surfaces was definitely subjected to deep scraping with a lithic blade or flake from the mesial part to the root tip (fig. $3, n^{\circ} 1$ and 2). Scraping was combined with abrasion on the surface of the would-be perforation. The initial dimensions of the hole altered due to its having been worn by suspension. In addition, the images obtained with the fibre-optic microscope have allowed us to observe a number of use-wear marks on the canine surface (fig. 3 , $\left.n^{\circ} 3\right)$.

A fox canine perforated towards the root tip was found during the 2014 archaeological excavation campaign (fig.2, $\mathrm{n}^{\circ} 4$ ). The tooth was broken in both proximal and distal parts. The biconical perforation for suspension was made almost exclusively by rotating a sharp flint point or another hard rock. This action was preceded by a preparation of the surface as indicated by the presence of few faint traces of scraping still preserved on the root (to flatten it) (fig. $3, n^{\circ} 4$ ). The canine surface has no stigmata resulted from the prolonged wearing of the ornament. Instead, evidence of usage by suspension of the ornament is easily noticeable on the perforation outline.

A second fox canine, broken since very old times, was found during the 2018 campaign (fig. $2, n^{\circ}$ 5). The perforation was made toward the tip of the root and is almost completely damaged. However, one of the faces still preserves some traces of the orifice.

The first perforated red deer canine was discovered in 2001 (fig. $2, n^{\circ}$ 6). As this sample is damaged in the perforation area, one cannot make too many technological observations on how it was made. In fact, only one side of 

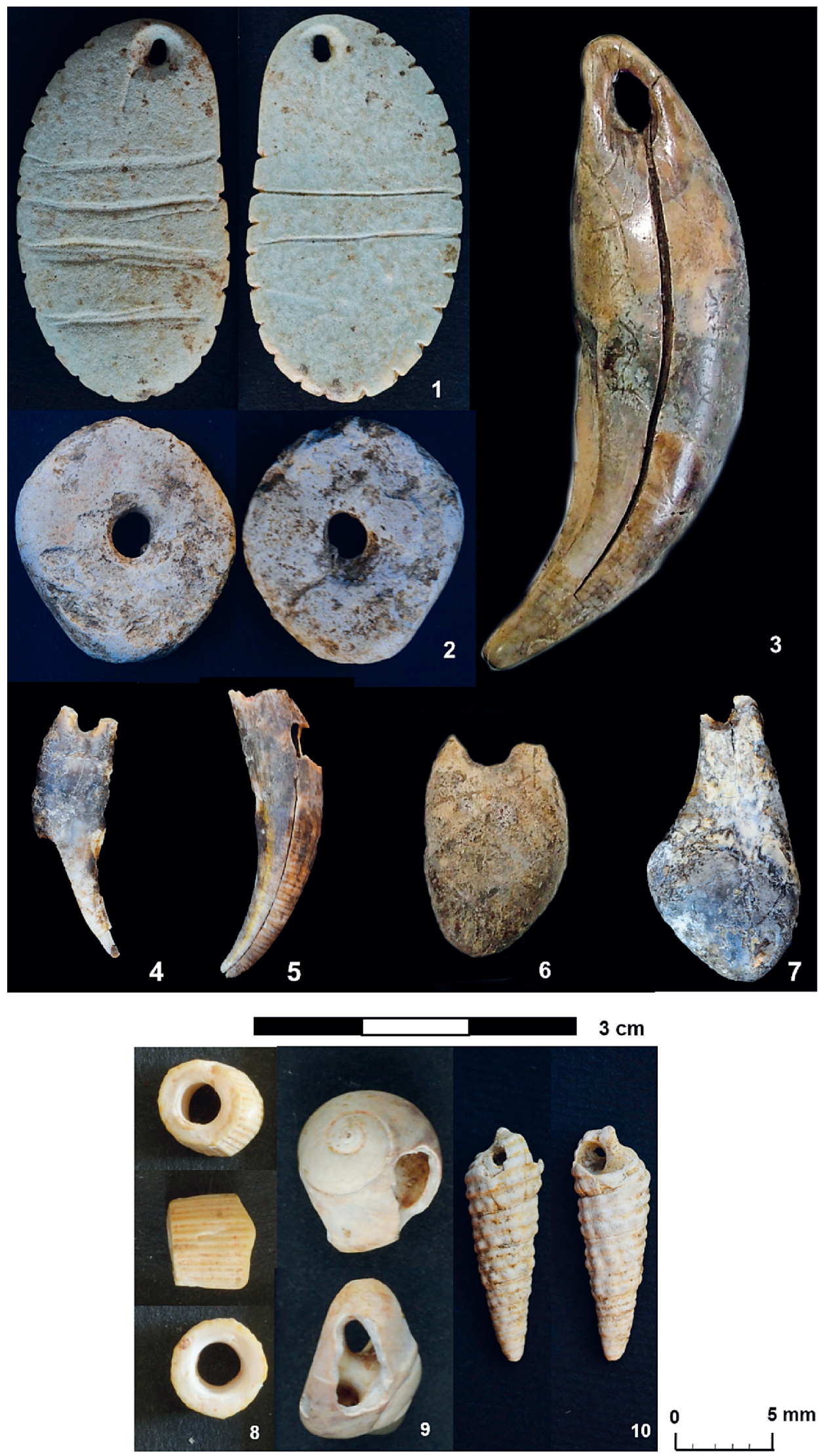

\section{FIGURE 2}

Ornaments found in the Gravettian I of Poiana Cireșului. 1 - engraved siltite pendant; 2 - calcareous marl bead; 3 - perforated wolf canine; 4-5 - perforated fox canines; 6-7 - perforated red deer canines; 8 - Dentalium sp.; 9 - Tritia sp.; 10 - Potamides bicostatus.

Parures de couche Gravettien I, découvertes à Poiana Cireșului : 1 - pendentif gravé en silt ; 2 - perle fait en marne calcaire; 3 - canine de loup perforée; 4-5-canines de renard perforées; 6-7 - canines de cerf perforées : 8 - Dentalium sp. ; 9 - Tritia sp. ; 10 - Potamides bicostatus.

the perforation has remained unaffected and allows us to state that perforation was definitely made from this part also. There are no visible marks of wearing on the tooth surface. In 2014, a second red deer canine was recovered. It is burnt, as it was found near a hearth (fig. $2, n^{\circ} 7$ ). The perforation intended for suspension is to be found at the tooth root. The upper part of the perforation is missing, having been destroyed in early times. Enough of the perforation has been preserved to let one note that working was done from both faces. The area intended for 

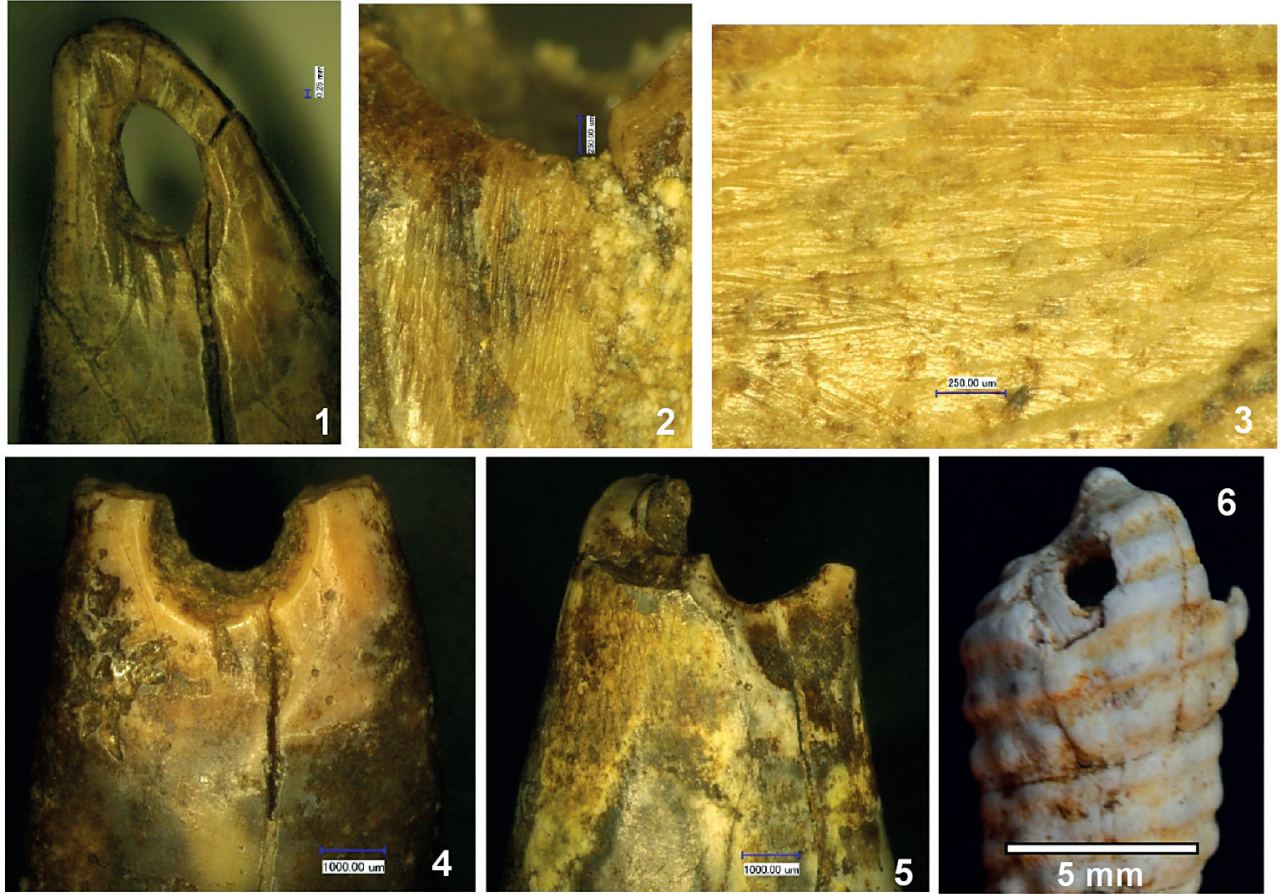

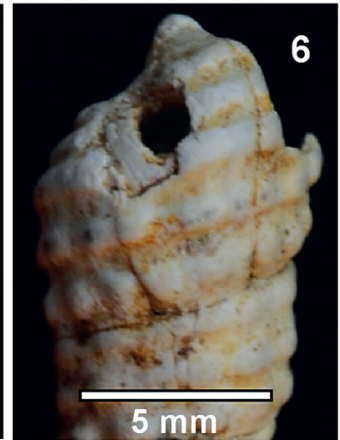

\section{FIGURE 3}

Ornaments found in the Ornaments found in Gravettian I of Poiana Ciresului. Perforation method and use-wear traces on perforated wolf canine (1-3), fox canine (4), red deer canine (5) and Potamides bicostatus shell.

Parures de couche Gravettien découvertes à Poiana Cireșului. Méthodes des perforations and traces d'usure sur le canines percée de loup (1-3), renard (4), cerf (5) et coquille de Potamides bicostatus. perforation was first prepared through quite obvious detachments (fig. $3, n^{\circ} 5$ ), which is visible on one of the faces. It is very interesting that on both tooth faces there is reliable evidence of wearing on a flexible organic material and the use-wear are almost similar to those on the wolf canine (fig. $3, n^{\circ} 3$ ). These traces are more obvious and easy to notice on the canine convex faces, which came into direct and permanent contact with the flexible material (maybe clothes) (Cârciumaru et al. 2018).

\subsection{3 | Perforated shells}

The 2015 archaeological excavations in section XII also revealed the first perforated shells in this level: a Dentalium bead (fig. $2, n^{\circ} 8$ ) and a whole specimen and a fragmented specimen of the Tritia sp. (fig. $2, n^{\circ} 9$ ).

The Tritia specimen have a maximum diameter of $8.1 \mathrm{~mm}$ and $4.9 \mathrm{~mm}$ high and was post-depositionally affected, with only the upper substrate of the ostracum breaking off, in some parts, from the outer shell surface and in some other parts the second substrate being absent, thus reaching the hypoostracum or the nacre. As specific stigmata are missing, the technological chain which led to the transformation of the Tritia shell into an ornament is hard to recreate. The perforation was greatly altered due to prolonged wearing by suspension of the shell. A second shell of the Tritia sp. was also found. Since the specimen is fragmented, only its $4 \mathrm{~mm}$ height could be specified. However, the sample is smaller than the previous one (Cârciumaru, Nițu 2018; Cârciumaru et al. 2018).

Also in 2015, the first and, so far, the only bead of Dentalium sp. from the Palaeolithic in Romania was found in the Gravettian I layer (fig. 2, $n^{\circ}$ 8). The Dentalium bead from Poiana Cireșului is small: maximum length $-4 \mathrm{~mm}$, minimum length $-3.3 \mathrm{~mm}$, large diameter $-4.5 \mathrm{~mm}$, small diameter $-4.2 \mathrm{~mm}$, while the thickness of the wall is about $1 \mathrm{~mm}$. Although the bead dimensions are very small, the truncated cone shape typical of the species morphology is preserved. The shell contour preserves most of the ribs of the species. In addition, at the two extremities, traces of wearing are observed.

In 2018 a perforated shell of Potamides bicostatus was found, which is a novelty for the Palaeolithic in Romania (fig. $\left.2, n^{\circ} 10\right)$. It is a fossil species that has been identified in deposits attributed to the Sarmatian in the Moldavian Plateau. An outcrop in which this species occurs has been mentioned quite close to Poiana Cireșului, less than $100 \mathrm{~km}$ away (Ionesi 2006). The shell recovered is almost intact, being damaged only in the upper part of the aperture since old times. The hole overlaps the last three whorls and is elongated due to wearing by suspension. The resulted stigmata are visible in the upper part of the hole. The hole was made from the outside by abrasion and then by penetrating the surface with a lithic tool (fig. $3, n^{\circ} 6$ ).

The ornaments discovered in the third Gravettian layer (26/27 ka uncal. BP) at Poiana Cireșului are completely different from those found in the first level and include an association of perforated shells not found in any other Gravettian settlement (Nitu et al., 2019). The perforated shells come from three species of molluscs: freshwater Lithoglyphus naticoide and Lithoglyphus apertus as well as Homalopoma sanguineum (an exclusively Mediterranean species). These gastropods belonging to species that are very rare in the Gravettian.

Over the course of several campaigns carried out from 2004 to 2018, 41 perforated shells of Lithoglyphus naticoides (fig. 4, A, $n^{\circ} 1-41$ ) and 3 of Lithoglyphus apertus (fig. 4, A, $n^{\circ}$ 42-44) were recovered from the Gravettian III layer (Cârciumaru, Tutuianu-Cârciumaru 2012; Nițu et al. 2019). Ten specimens of L. naticoides found in 2004 and two others recovered in 2006 were considered to be part of the same necklace or bracelet as they were concentrated in a small area. One of the specimens discovered in 2004 is black due to burning processes (fig. 4, $n^{\circ} 7$ ). The Lithoglypus naticoides perforated shells from Poiana Ciresului come mostly from mature specimens, but in 

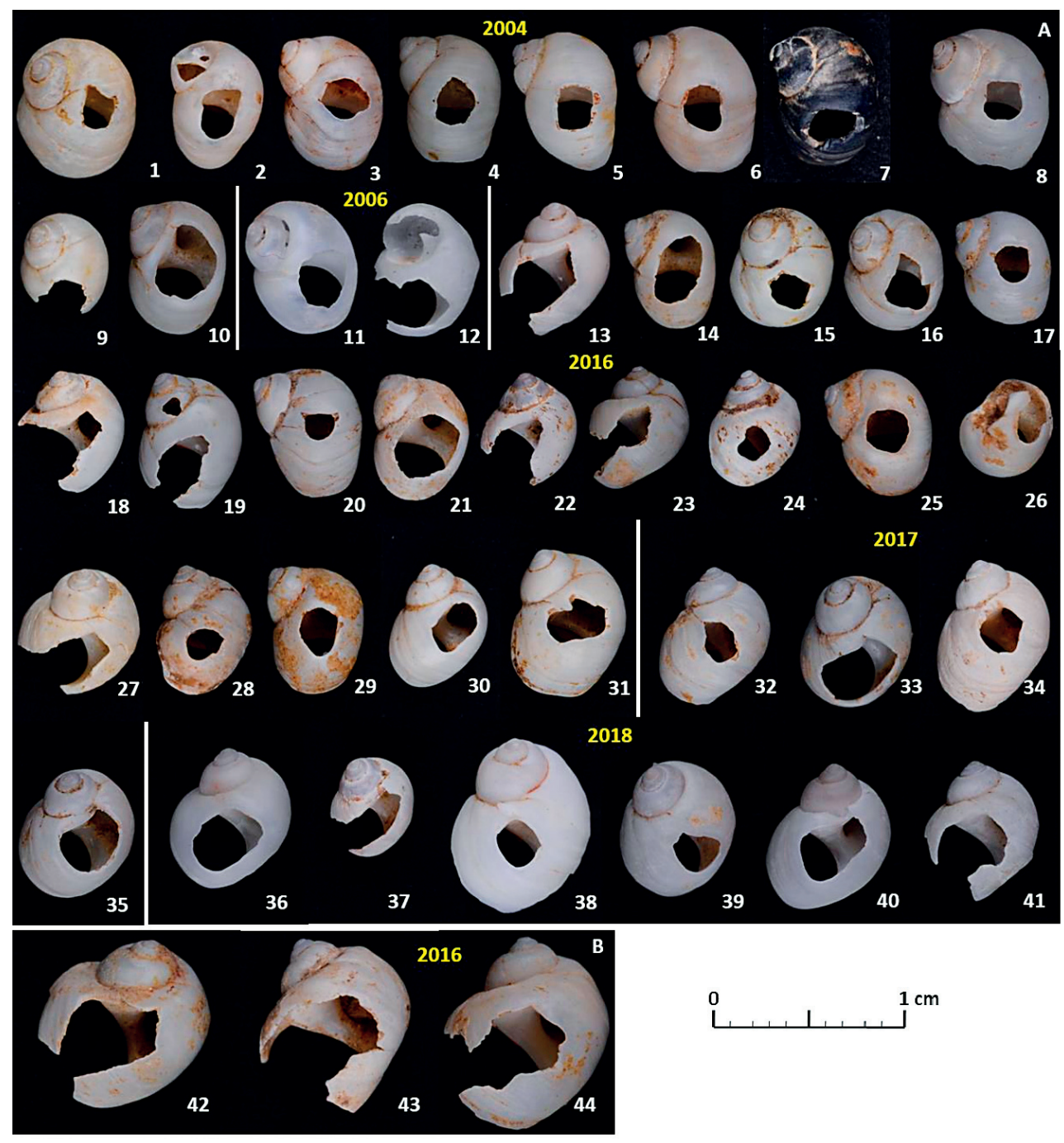

\section{FIGURE 4}

Ornaments made of shells of the Gravettian III layer at Poiana Ciresului-Piatra Neamt. Lithoglyphus naticoides $(A=1-41)$ found in 2004, 2006, 2016-2018; L. apertus $(B=42-44)$ found in 2016; Homalopoma sanguineum (C) found in 2016.

Parures de coquilles de couche Gravettien III à Poiana Cireșului Piatra-Neamt,. Lithoglyphus naticoides $(A=1$-41) découvertes en 2004, 2006, 2016-2018 et de Lithoglyphus apertus $(B=42-44)$ découvertes en 2016 ; Homalopoma sanguineum découvertes en 2016. terms of dimensions, young specimens were also used. The maximum diameter, for the majority of specimens, exceeds $6.3 \mathrm{~mm}$, while the minimum is over $5 \mathrm{~mm}$. The largest specimens have the maximum diameter of $7.7 \mathrm{~mm}$ and the minimum diameter of $5.8 \mathrm{~mm}$. Despite their frail appearance at first sight, of the 41 specimens only 11 have been fragmented since old times (fig. 4) (Nitu et al. 2019). Three perforated Lithoglyphus apertus shells were found in 2016 (fig. 4, $n^{\circ}$ 42-44). Unfortunately, all specimens of $L$. apertus recovered are fragmented, which makes the measurement of dimensions somewhat unreliable. In these conditions, the maximum diameter (height) varies between 10.1 and $9.1 \mathrm{~mm}$, whereas the width is between 8.5 and $7.9 \mathrm{~mm}$. The perforation of each shell was designed for suspension and the resulting marks confirm that they were worn for a shorter or longer period; this is shown by the technological study conducted through microscopic observations, which helped capture extremely revealing images of the use-wear areas resulted from their utilization by suspension (Nițu et al. 2019). According to 
some studies (Taborin 1993a, b; d’Errico, Jardón-Giner, Soler-Mayor 1993; d'Errico et al. 2005; Avezuela 2010) and after the experiments we have made (Cârciumaru, Tutuianu-Cârciumaru 2012 ; Nitu et al. 2019), it has been concluded that all the Lithoglyphus shells of Poiana Cireșului were perforated from the inside by pressure exerted with an antler or hardwood sharp point inserted through the aperture after the shell had been fastened to a fixed blank. The position of the orifice on the last whorl of the shell was chosen so as not to endanger the resistance of that specimen, on the one hand, and to ensure an efficient hanging, so that the centre of gravity should determine a relatively similar position for all items and, finally yet importantly, answer the aesthetic requirements intended.

During the 2016 archaeological excavations of Poiana Cireșului, 10 perforated shells of the Homalopoma sanguineum species were discovered in section XII (fig.4, B, $n^{\circ}$ 1-10) (Nițu et al. 2019). These specimens were found alongside of the Lithoglyphus ones. The Homalopoma sanguineum currently lives in the Mediterranean Sea and it is assumed that the species also existed in cold Würmian periods and that the cold climate in this stage did not cause the disappearance of this species (Taborin 1993a) The Homalopoma sanguineum perforated shells found at Poiana Ciresului generally come from mature specimens, most of them with a maximum diameter of over $6.40 \mathrm{~mm}$ and the minimum of at least $5.23 \mathrm{~mm}$. The largest of the specimens has the maximum diameter of $8.14 \mathrm{~mm}$ and the minimum diameter of $6.99 \mathrm{~mm}$, while the smallest has a maximum diameter of $5.78 \mathrm{~mm}$ and the minimum of $4.96 \mathrm{~mm}$. Of the 10 specimens found, three are broken: one with a still complete hole and two with fragmented holes. In all three of them, the fractures are old. One of the specimens with damaged hole is the smallest of those discovered. There is great unity as regards the execution of the perforations. In all the specimens, the hole was made in the middle of the umbilicus, i.e. on the last anfract or whorl. It is located near the suture between the umbilicus and the whorl preceding it. Technologically, were perforated with grinding and gouging, a motion that involve pressure and rotation (Nitu et al. 2019). There are certain aspects that point to the Homalopoma sanguineum shells were worn by suspension: there is a clear rounding in the area that came in permanent contact with the suspension thread and intense polishing. Furthermore, the shells have utilization marks on both the dorsal and ventral sides and this most likely resulted from the beads' friction against each other (they were strung in the shape of necklaces or other similar ornaments) (for more details, see Nițu et al. 2019).

\section{3 | MITOC-MALU GALBEN}

\section{1 | Site background}

The Palaeolithic settlement of Mitoc-Malul Galben is located along the Ghireni brook, a right tributary of the Prut river, about $500 \mathrm{~m}$ from their confluence on the territory of Mitoc commune, Botosani County, Romania ( $48^{\circ} 07^{\prime}$ North latitude and $27^{\circ} 02^{\prime}$ East longitude). At the bottom of the terrace deposit, were identified three Aurignacian occupation dated between 32.700 and 29.500 uncal. BP, some Aurignacian traces being present until 27.500 BP The four Gravettian layers provide the following datings: Gravettian layers I and II are developed between 27.500 and 25.500 uncal. BP; layers III and IV are dated between 24.000 and 23.000 unca. BP In this settlement, the lithic materials are dispersed on the surface, sometimes being discovered around some simple hearths.

\section{2 | Ornaments description}

\subsection{1 | Stone pendant}

The archaeological excavations of 1981 led to the discovery of an "amulet-pendant" in the lower Gravettian level (fig.5, $n^{\circ}$ 1) (Chirica 1982; Chirica, Noiret 2007). The pendant was made from a "middle cortical flake", $3.4 \times 3.4 \times 0.8 \mathrm{~cm}$, ovalshaped, slightly concave at the base, i.e. the part opposite the perforation (Chirica 1982 - p. 229). In terms of the decoration on both faces, we believe that the interpretation of C. Beldiman (2004) is accurate, in that the two surfaces of the cortex were first prepared by scraping and only after that the decoration, consisting of engraved straight and curved, radially arranged lines with asymmetric $V$ or $U$ profile, was made. The biconical perforation was achieved through an alternative rotation. The pendant circumference is decorated with 23 notches parallel to each other and placed perpendicular to the blank axis, 7 on the two convex sides and 9 on the concave side. Initially, it was claimed that the Mitoc-Malu Galben pendant dated back to 20,495 \pm 850 B.P. (GX 8503) (Chirica 1982), but later the age of $26,700 \pm 1.040$ B.P. $(G X-9.418)$ (Chirica 1989) was provided. This dating is part of a series of dates characteristic of the Gravettian II level from MitocMalul Galben (Chirica 1989). The ambiguity of the age of this pendant has recently been dealt with (Cârciumaru, Nițu 2018).

\subsection{2 | Bone pendant}

In 1993, a pendant made of a fragment of large herbivore diaphysis was found in the Gravettian IV layer, 4.83 m deep. It was almost entirely preserved, except a small part in the perforation area, which was lost during excavations (fig. 5, $n^{\circ} 2$ ). C. Beldiman conducted a technological study of the pendant, with revealing images of the working marks preserved on its surface (Otte et al. 1995). The blank shape is relatively trapezoidal, with slightly curved sides and two somewhat curved convergent faces. On the upper face, one can notice series of fine and sometimes clearer striations, generally parallel, oblique or transversal, owing to the shaping of the item. The perforation is biconical, located rather eccentrically towards the right of the upper face. Technically, the two longitudinal planes of the blank were obtained by bone fracturing, most likely by launched direct percussion, while the two extremities were sectioned through bending or sawing, after which the surfaces were shaped by multidirectional scraping (Otte et al. 1995). Several C-14 dates have been provided for the Gravettian IV from Mitoc-Malul Galben, in which the bone pendant was found isolated, ranging from 20,945 \pm 850 B.P. (GX-8503) to $19,910 \pm 990$ B.P. (GX-8724) (Chirica 1989). 

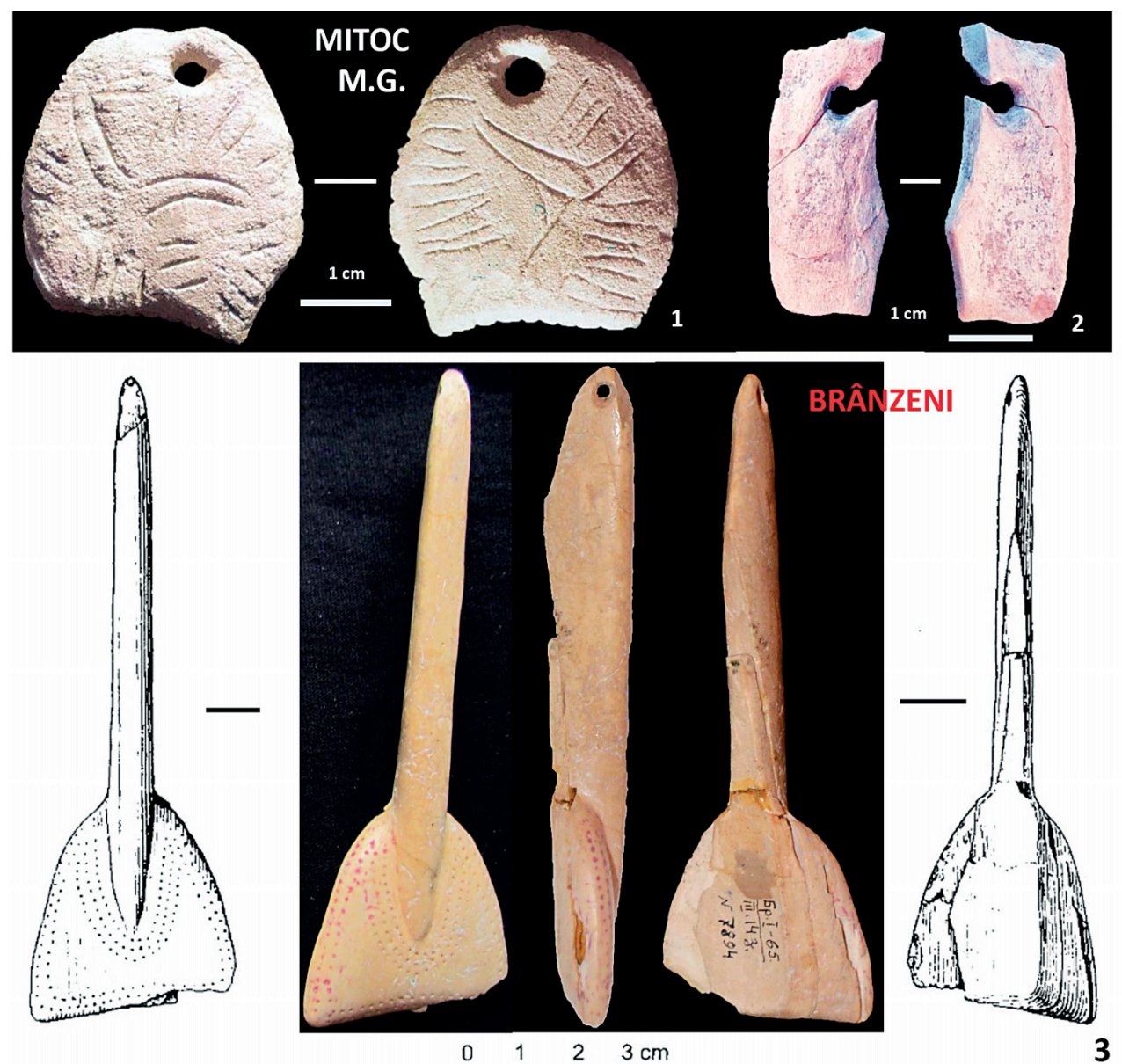

\section{FIGURE 5}
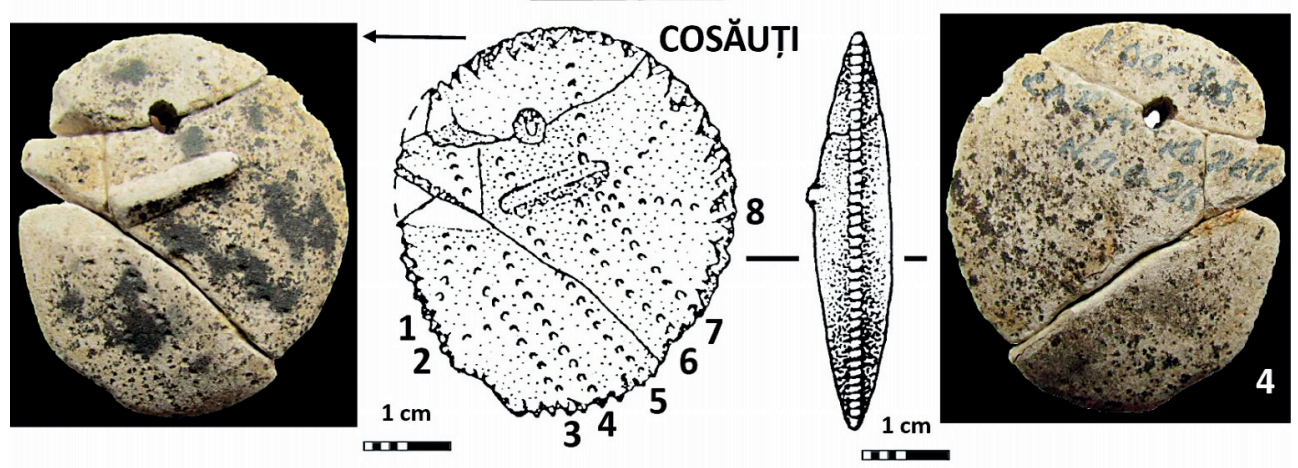

Pendants found at Mitoc-Malu Galben (1-2), in the Brînzeni cave (3) and the open-air settlement of Cosăuti (4) (drawing after P. Noiret, 2009 (3) and I. Borziac, C.-V. Chirica, 1996 (4).

Pendentifs découverts à MitocMalu Gaalben (1-2), dans la grotte de Brînzeni (3) et dans l'établissement en plein air de Cosăuți (4) - dessins de P. Noiret 2009 (3) et I. Borziac, C.V. Chirica, 1996 (4).

\section{4 | THE BRÎNZENI CAVE}

\section{1 | Site background}

It is located $1.2 \mathrm{~km}$ away from the village of Brînzeni in Edinet District, Mersâna suburb, in the Republic of Moldova. The cave was carved in the limestone rocks $100 \mathrm{~m}$ above the level of left bank of the Racovet river, about $8 \mathrm{~km}$ away from its confluence with the Prut river ( $48^{\circ} 05^{\prime}$ North latitude and $27^{\circ} 08^{\prime}$ East longitude). The entrance is oriented to the north, approximately $65 \mathrm{~m}$ above the river thalweg. Inside, the ceiling sometimes reaches more than $4 \mathrm{~m}$ in height and the large entrance allows for a good illumination of the cave interior, which is only $17 \mathrm{~m}$ long and $14 \mathrm{~m}$ wide. The cave was found by $\mathrm{N}$. A. Chetraru and V. Verina in 1960 and the first survey was also conducted the same year. Later in 1963, 1964-1965, 1968 and 1975, N. A. Chetraru carried out systematic excavations in the cave deposit (Chetraru 1965a), which

were continued in 1987 by I. Borziac (Borziac 1994 ; Borziac, Chetraru 1996). The first investigations conducted by N. A. Chetraru and even those of I. Borziac mentioned very old cultural classifications of the deposit. These cultural assignations based on the restudy of the lithic material were interpreted in subsequent studies and are now in accordance with the C-14 dates of the cave deposit and the terrace in front of it, which range between 26,600 \pm 370 B.P. (OxA-4122) and $14,700 \pm 130$ B.P. (OxA-4120) (Chetraru 1970 ; Noiret 2009).

\section{2 | Ornaments description}

In addition to a horse incisor, partially polished and flattened on the two edges, which still preserves, at its root, the marks of a perforation $2.5 \mathrm{~mm}$ in diameter, retrieved by I. Borziac in 1991 (Borziac, Chetraru 1996), N. A. Chetraru found a very interesting ivory pendant (whom he considered an "amulet") in the central area of 
the Brînzeni cave, in 1965 (fig. 5, n 3) (Chetraru 1989). Stratigraphically, this pendant is thought to belong to the lower level of the cave, for which there are two C-14 dates: OxA-4122: $26,600 \pm 370$ B.P. and OxA-4124: $26,200 \pm 360$ B.P. (Noiret 2009). The item consists of two different registers: the upper part is a flat elongated blade, with a relatively triangular section and a biconical perforation towards the point, while the lower part has the appearance of an irregular triangle. Two sides of the triangle are slightly curved and the base is irregular. The item is $111 \mathrm{~mm}$ long and 38 to $7 \mathrm{~mm}$ wide. The thickness of the upper part reaches $17 \mathrm{~mm}$ and of the lower one, $11 \mathrm{~mm}$. One of the triangle faces and the middle part of one side of it are decorated with dots aligned on several regular rows (Chirica, Borziac 1995). The decoration on the right side of the upper part consists of four rows of dots. The first row has 27 dots, the second 10 dots, the third 9 dots and the fourth, which is more deteriorated, preserves only three dots. At the contact with the upper elongated part of the item, one of the triangular faces is decorated with 78 dots arranged in three oval rows. The decoration is completed by 100 dots flanking the triangle sides in the lower part of the pendant. It is considered that the edges were damaged due to the wearing of the suspended pendant on a leather or wool garment (Borziac, Chetraru 1996). Z. Abramova (1995) regards this pendant as an enigmatic object, maybe even an unmatched statuette.

\section{5 | THE DURUITOAREA VECHE CAVE}

\section{1 | Site backround}

The cave is located on the left bank of the Ciuhur brook, $2.7 \mathrm{~km}$ away from its confluence with the Prut east of Costești, Râşcani district, the Republic of Moldova. The cave stretches out from south to north and has three distinct compartments extending $49 \mathrm{~m}$ in length. The cave width varies between 9 and $5 \mathrm{~m}$. The first two surveys of 2 sq. m each were conducted by N. A. Chetraru in 1958-1960, when it was found that the Palaeolithic occupation is concentrated in the central and southern compartment (Chirica, Borziac 2005), and were continued in 1965 (Chetraru 1965b). Culturally, the upper level 2 in this cave was attributed to the Gravettian (Borziac 1994). A C-14 date of $24,000 \pm 600$ B.P. (Le 11,813) confirms this.

\section{2 | Ornaments description}

\subsection{1 | Ivory pendant}

The ivory pendant is fragmented at one side (fig. $6, n^{\circ} 1$ ). Because of this, it is difficult to reconstitute its initial shape. Its current dimensions are: $36 \mathrm{~mm}$ long, $18 \mathrm{~mm}$ wide and $5 \mathrm{~mm}$ thick. The hole is slightly biconical and has marks of wearing (perforation deformations). The two pendant faces were post-depositionally damaged, which led to the exfoliation of a large part of those surfaces. That is why the initial engravings decorating the pendant have been destroyed for the most part. Only a linear decoration consisting of a few parallel lines, quite distant from each other, can be seen. The space between them might have been filled with inclined incisions. This item was interpreted by Chirica and I. Borziac (1995) as a bracelet fragment.

\subsection{2 | Bone and stone pendants}

- Pendant made of flat bone flake with a slightly undefined shape (fig. $6, n^{\circ} 2$ ). The bone blank does not seem to have undergone any special working. In the current shape, both surfaces are quite polished, but the marks do not allow us to say whether it is a natural or anthropic process. The hole is biconical and suffered a significant alteration, maybe due to long wearing. Both the ivory and the bone flake pendants from the Duruitoarea Veche cave have been erroneously described as being made of calcite (Abramova 1995 - p. 121, fig. 1/1-2).

- The bone flake perforated in the middle is certainly a curious item (fig. $6, n^{\circ} 4$ ). It may rather have a practical utility, in that it may be some kind of clothing fastener. Probably a leather string with a knot that fastened the bone item to the garment was introduced through the hole. Naturally, if this item was intended to be a clothing accessory, it may as well be regarded as an adornment piece. One should also not neglect the assumption that this item may have been a pre-shape.

- Belemnite pendant manufactured from the mesial part of a fossil cephalopod shell of this species. The pendant blank was cut from the inner shell belonging to a flattened species (fig. $6, n^{\circ} 3$ ). The inner grooves have been quite well preserved, which supports once more the assumption that this pendant was created from a belemnite. The fossilised cylindrical structure of belemnites (also known as rostrum) is mostly composed of calcite, which had led to confusions over the definition of the material this pendant was made of. Thus, it has been claimed that this pendant was worked from calcite (Abramova 1995 - p. 121, fig. 1/5), which is not wrong, but for greater accuracy it must be specified that it is a belemnite. The blank of this pendant was achieved as a result of several operations. First, a portion of the belemnite body was detached during a first action of longitudinal debitage, which meant roughly a half of its circumference. The proximal and distal parts were achieved by sawing, followed by a shaping, most likely by abrasion and polishing. The hole is biconical and was made by first preparing the surface by percussion and then by rotating a lithic tool made of a sufficiently hard raw material.

\subsection{3 | Ornaments on animal teeth}

- Intact perforated red deer canine with a length of $1.8 \mathrm{~cm}$ and a maximum width of more than $1 \mathrm{~cm}$ (fig. $6, n^{\circ} 5$ ). The canine still preserves the marks of a previous perforation. It is difficult to say if the first perforation was a failed initial attempt to turn the canine into an ornament or if it was damaged by wearing.

- Fragmented perforated red deer canine. The item is quite broken; in fact, the canine was incompletely reconstituted from several fragments (fig. $6, n^{\circ} 6$ ). The position of the perforation is totally atypical as compared to the usual way of perforating similar canines in the Palaeolithic, which is at the root in over $80 \%$ of the cases (BargeMahieu, Taborin 1991). It is just as plausible that it may have been redone by the Gravettian artisan, who was forced to make a perforation in the globular crown, constrained by the fact that the canine root had been damaged for some reason. 


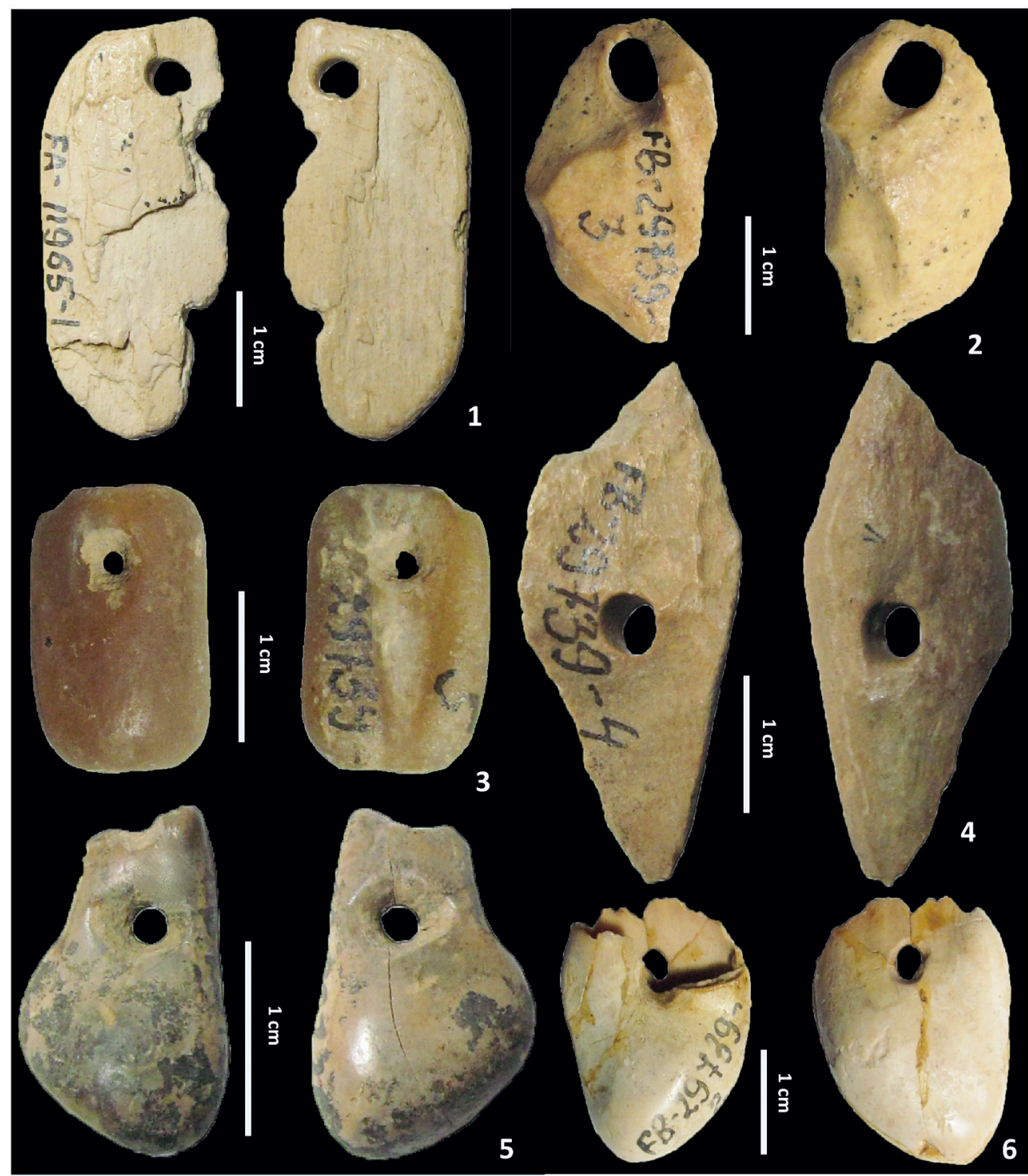

\section{FIGURE 6}

Ornaments from the Gravettian level found in the Duruitoarea Veche cave. 1-ivory pendant; 2bone pendant; 3-belemnite pendant; 4-bone flake perforated in the middle; 5-6 - perforated red deer teeth.

Parures découvertes au niveau Gravettien de la grotte de Duruitoarea Veche: 1 - pendentif en ivoire; 2 - pendentif en os; 3 - pendentif en bélemnite; 4 - éclat en os perforé dans la partie moyenne; 5-6 - canines de cerf perforées.

\section{6 | COSĂUȚ|}

\section{1 | Site background}

The Palaeolithic settlement is located $0.5 \mathrm{~km}$ away northwest of Cosăuți village, Soroca District, on the second terrace on the right bank of the middle Dniester, in the Republic of Moldova (48 $13^{\prime}$ North latitude and $28^{\circ} 15^{\prime}$ East longitude). It was found by I. Borziac and M. Anikovich in 1978, researched by I. Borziac from 1981 to 1991 and again from 1994 to 1995 with a team from the University of Liège led by M. Otte (Borziac 1991; 1993; 1996).

\section{2 | Ornaments description}

\subsection{1 | Pendants and beads made of stone, amber and fossils}

- Marl pendant sometimes described as an amulet pendant (Borziac, Chirica 1996), an amulet (Noiret 2009) or a mere pendant (Borziac et al. 1998). It was found in level $2 \mathrm{a}$ for which there are three $\mathrm{C}-14$ dates between $17,230 \pm 140$ B.P. (GrN 21,792) and 16,860 \pm 770 B.P. (LE 3304) (fig. $5, n^{\circ} 4$ ). At the moment of its discovery, the pendant was broken in four fragments which united formed a disc with a diameter of 5 to $4 \mathrm{~cm}$ and the section of $0.9 \mathrm{~cm}$ thick (Borziac, Otte 1996). The pendant circumference still preserves 60 incisions, given that, due to the item fragmentation, some of the have been damaged (it is estimated that there may have actually been 76 or maybe even 78 engraved incisions). The distance between them is about $1.2 \mathrm{~mm}$. It has been stated that the upper face of the pendant is decorated with a series of dots arranged linearly in different numbers in 9 rows (Borziac 1994; 1996; Borziac, Chirica 1996; Borziac, Otte 1996; Borziac, Otte, Noiret 1998). We believe that the engraved dots are arranged only in 8 rows, with actually a different continuity, as follows: $1=6 ; 2=2 ; 3=12 ; 4=15 ; 5=15 ; 6=17 ; 7=17 ; 8=6$ (fig. 4/4). Under the perforation, on the upper face, there is a protuberance $12 \mathrm{~mm}$ long, $3 \mathrm{~mm}$ wide and $1.4 \mathrm{~mm}$ high, about which we cannot say if it originates from the initial blank morphology or if the surface was intentionally worked in this way, as a sign of personalisation of the ornament. The upper surface in particular is covered with a layer of bitumen or resin, which blurs most part of the dot-shaped decoration of the pendant. This black layer is probably post-depositional. However, some traces of red and brown ochre have been noticed scattered on the pendant surface. 
- Amber pendant found in level 3a, with two dates of $18,000 \pm 180$ B.P. (OxA 5237) and 17,780 \pm 90 B.P. (GrA 7554). Unfortunately, this item could not be photographed and was not analysed.

- Hard sandstone pebble bead, which belongs to level 3 (fig. 7, $n^{\circ}$ 1), dated to between 18,030 \pm 150 B.P. (GrN 21359) and $16,160 \pm 250$ B.P. (GIN 4149). Its general morphology and the position of the hole, located in the middle, prompt us to consider this item a bead rather than a pendant, as it has been defined so far (Borziac at al., 1998; Noiret 2009). - The white marl bead also recovered from level 3a has a trapezoidal shape and a one of the face is rounded (fig.7, $n^{\circ} 2$ ). It was defined as a pendant (P. Noiret, 2009) or even interpreted as a spindle whorl (Borziac, Chirica 1996), but without any demonstration element. The hole is biconvex. -Three very small beads have also been found in level 3a. They are made of fossil coral (fig. $7, n^{\circ} 12-14$ ) which is to be encountered in the Sarmatian limestones around the settlement (Borziac et al. 1998).

\subsubsection{Ornaments on animal teeth}

In the third level three perforated red deer teeth have been found (fig. 7, $n^{\circ} 7-9$ ), previously published as reindeer teeth (Noiret 2009), while level 3b (Oxa 5235: 18.,000 180 B.P. LE 3307: $17390 \pm 580$ B.P.) has provided other perforated teeth, of which one is red deer and two are fox (Borziac et al. 1998 ; Chirica, Borziac 1995 ; Noiret 2009). We have found that indeed 4 red deer perforated canines and 4 fox canines have been discovered at Cosăuți (fig. 7, n 3-9).

\subsection{3 | Perforated shells}

A perforated fossil mollusc shell has been mentioned as well (fig.7, $n^{\circ} 10$ ), without mentioning the species to which it belongs (Noiret 2009). Meanwhile, another fossil snail shell, which was perforated, has been found among other materials (fig. $\left.8, n^{\circ} 11\right)$. The species to which it belongs has not been determined yet.

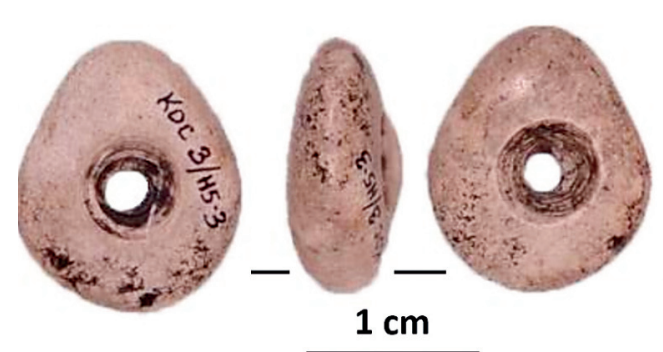

1
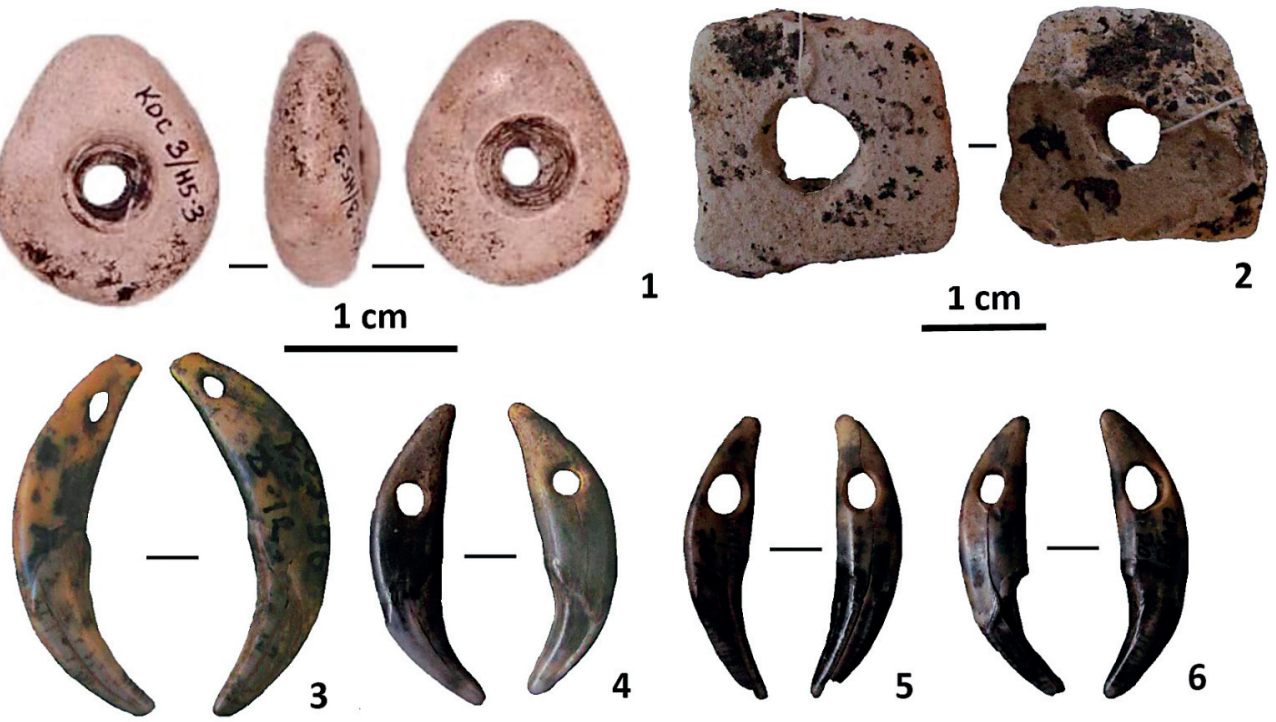

4
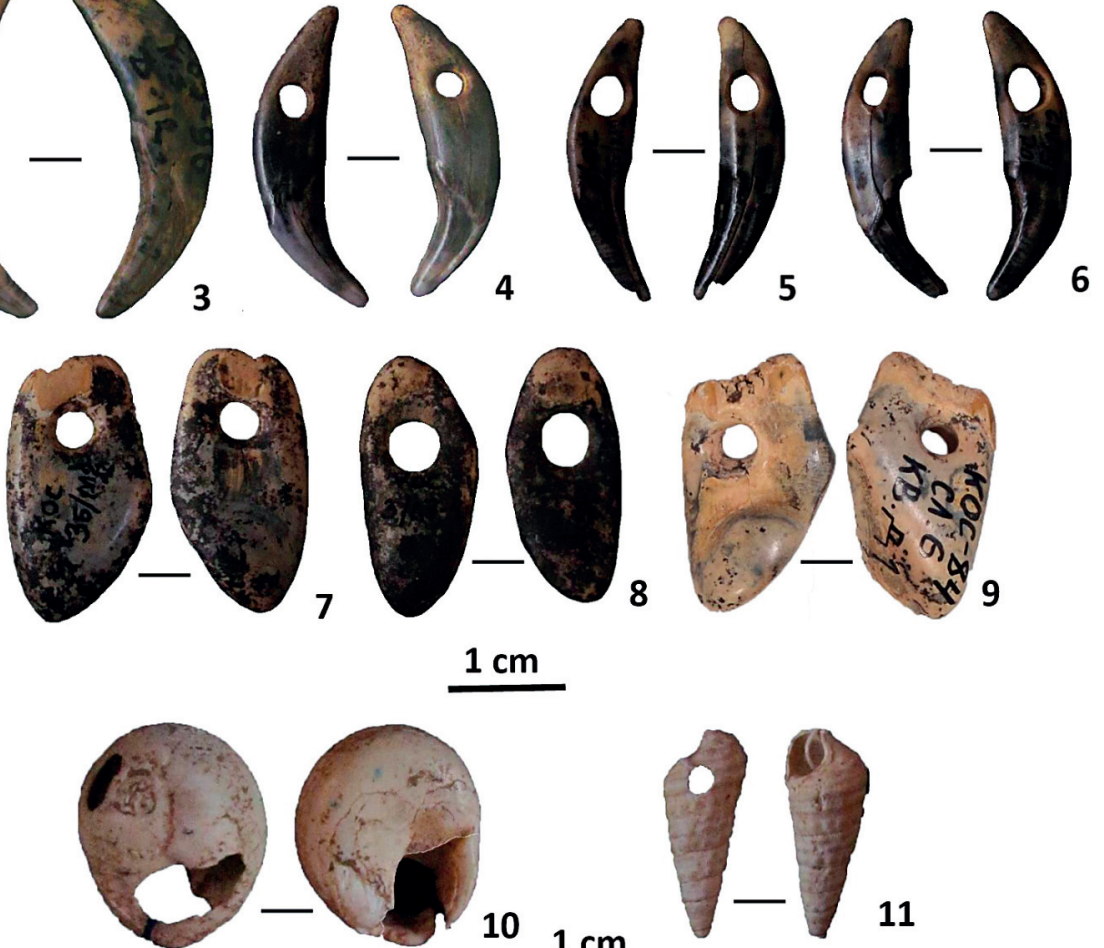

$1 \mathrm{~cm}$

\section{8}

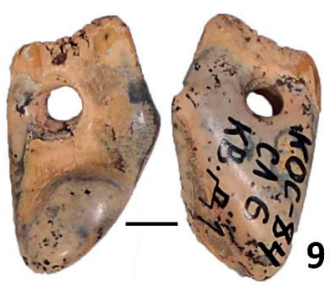

10

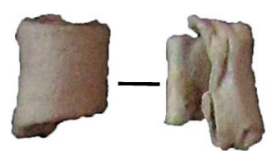

12

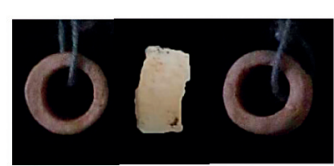

13

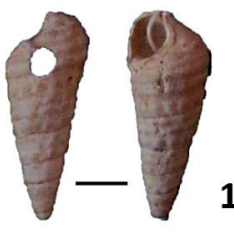

11

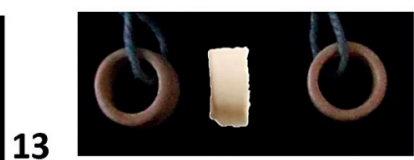

14
FIGURE 7

Ornaments from the Gravettian at Cosăuți. 1-sandstone pebble bead; 2-marl bead; 3-6 - perforated fox canines; 7-9 - perforated red deer teeth; 10-11 - perforated gastropod shells; 12-14 - fossil coral beads.

Cosăuți : 1 - perle en grès; 2 - perle en marne; 3-6- canines de renard perforées; 7-9 - dents de cerf perforées; 10-11 - coquilles de gastéropodes perforées: 12-14 - perles en corail fossile. 

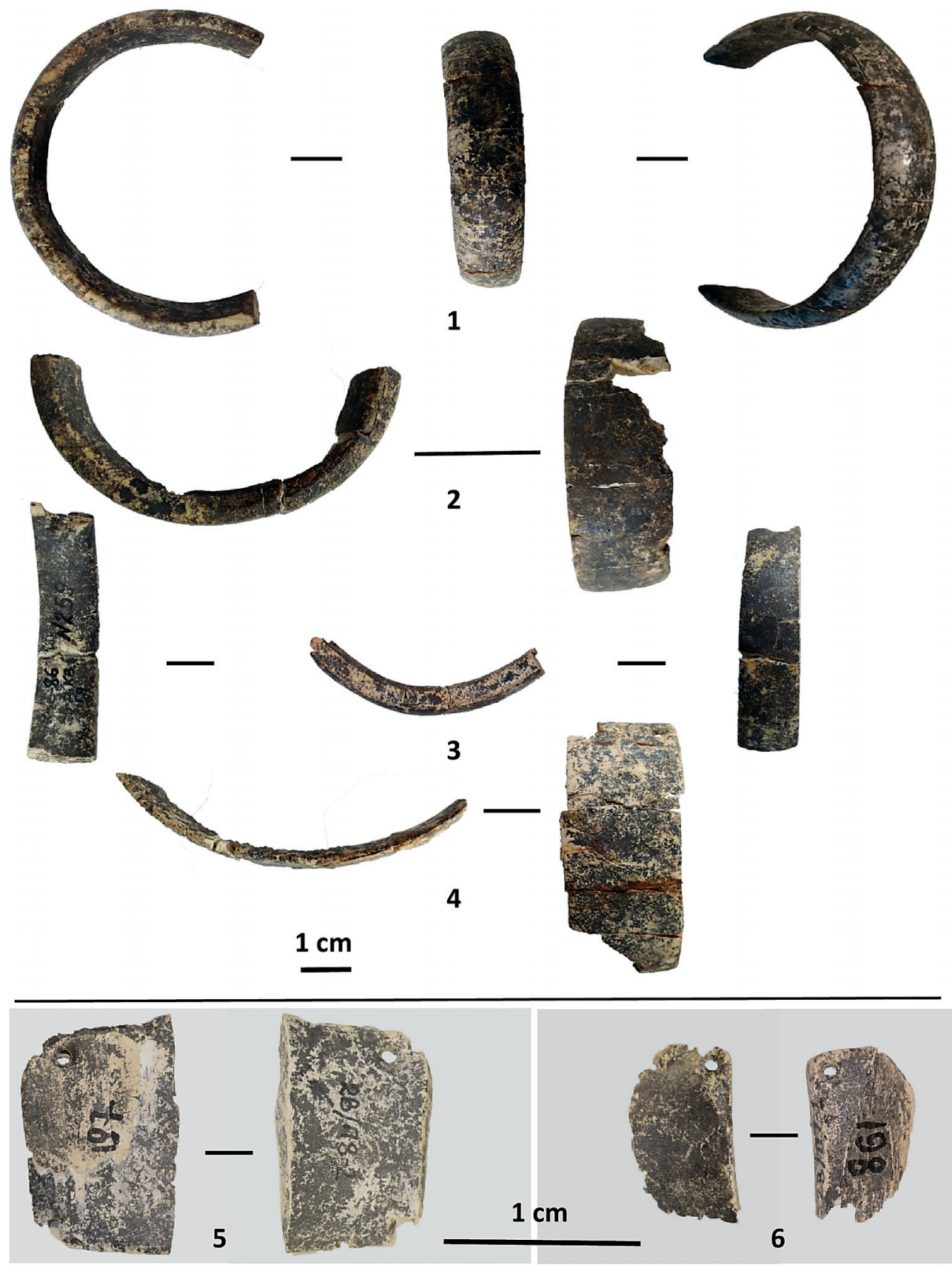

\section{FIGURE 8}

Fragmented ivory bracelets found in the Gravettian at Cosăuți.

Fragments de bracelets en ivoire, découverts dans le Gravettien de Cosăuți.

\subsection{4 | Ornaments made of ivory}

Ivory bracelets are quite well represented in the settlement of Cosăuți, even though they are generally fragmented. One such fragment, which was part of a bracelet made out of several items, has been retrieved from level 3 a (fig. $8, n^{\circ} 4$ ). The surface preserves working marks and three perforations. Level 3 has also provided three fragments of ivory bracelets (fig. $8, n^{\circ} 1-3$ ), while two other fragments with elliptic section come from level $2 \mathrm{C}$

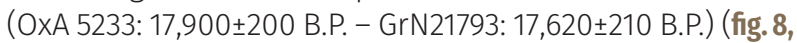
$\left.n^{\circ} 5-6\right)$. One of them has only one perforation, the other preserves two perforations (Borziac et al. 1998).

\section{7 | CLIMĂUȚI ||}

\section{1 | Site background}

The settlement of Climăuți is located to the right of the Dniester, in the village of Climăuții de Jos, Soldănești District, the Republic of Moldova (47'56' North latitude and $28^{\circ} 48^{\prime}$ East longitude). All the ornaments belong to the upper layer that provide a dating of $20.335 \pm 230$ BP (Lu-284). 


\section{2 | Ornaments description}

\subsection{1 | Ornaments made of ivory}

This site has given a number of ivory bracelets, some of which are particularly important in understanding how such ornaments were made (Borziac et al. 1992; Chirica, Borziac 1995; Borziac et al. 2007). One of the fragmented ones is a rectangular plaque $7.1 \mathrm{~cm}$ long, $3.7 \mathrm{~cm}$ wide and $1 \mathrm{~cm}$ thick. It is polished on both faces and on the smaller sides, while the long sides are fragmented (fig. $9, n^{\circ} 3$ ). The second is $6 \mathrm{~cm}$ long, $3.4 \mathrm{~cm}$ wide and $1.7 \mathrm{~cm}$ thick (fig. 9, $n^{\circ} 4$ ). Both have a slight curvature typical of such ornaments, but sadly, they lack the holes necessary for fastening in such cases.

There are two ivory pre-shapes at Climăuți, intended for the making of bracelets in various stages of completion. One of the items consists of a piece of cylindrical piece removed from a mammoth tusk, with a maximum diameter of $8 \mathrm{~cm}$ and thickness of $4.5 \mathrm{~cm}$, cut by transversal sawing. Between the hole placed in the centre and the edge of the item, the concentric layers of the tusk were removed on both sides up to $1.5 \mathrm{~cm}$ deep, resulting in a biconical shape (fig. $8, n^{\circ} 1$ ). The hole was made first, which would further facilitate the gradual removal of the ivory layers until the desired thickness of the bracelet was obtained. Final modification of the sides and outer surface, possibly including the decorations, was later achieved. Such a scenario is confirmed by the shape of another specimen found in the settlement of Climăuți II (fig. 9, $n^{\circ}$ 2).

\subsection{2 | Perforated shells}

The Climăuți II settlement has revealed an important collection of 60 shells, 24 of which are relatively intact and preserve a perforation. These are fossil shells of Sarmatian age from the deposits flanking the valley of the Dniester, attributed to at least two species, Cerithium vulgatum and Tritia reticulata (the old name was Nassa reticulata) (fig. 10, $n^{0} 7$ ). 15 shells were apparently stained with red ochre. All specimens were scattered over the entire excavated area (Borziac et al., 2007).
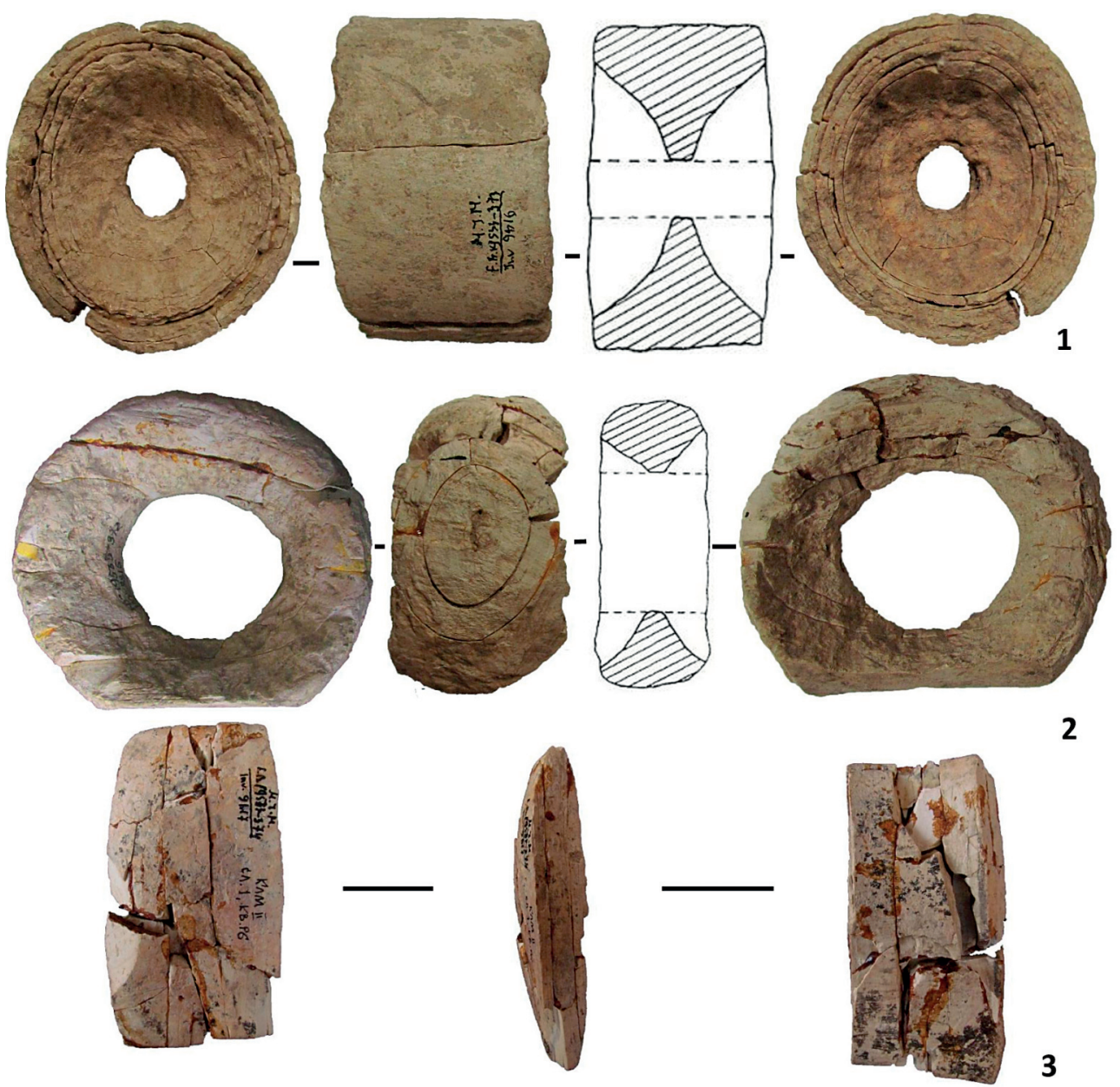

2
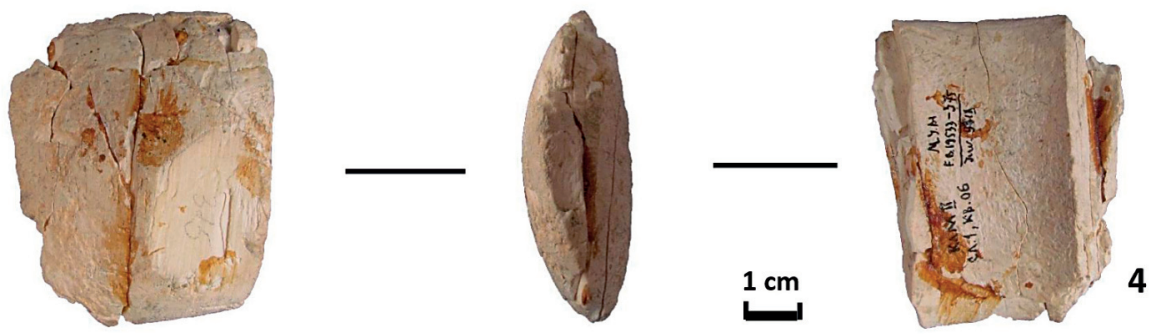

3

\section{FIGURE 9}

Ivory fragmented bracelets (3-4) and pre-shapes intended for the making of bracelets (1-2) in the settlement of Climăuți (drawing after P. Noiret, 2009).

Fragments de bracelets (3-4) et préformes en ivoire pour produire des bracelets (1-2) du site de Climăuți. 


\subsection{3 | Bones beads}

Five tubular bone beads $1 \mathrm{~cm}$ thick, stained with red ochre, complete the collection of ornaments in this settlement (fig. 10, $n^{\circ} 1-5$ ). Four of them have clear incisions on the outer surface (fig. 9, $n^{\circ} 1,3-5$ ). A rectangular bone with incisions on the long sides and a hole in the middle has also been found (fig. $10, n^{\circ} 6$ ).

\section{8 | MOLODOVA V}

\section{1 | Site background}

The settlement of Molodova $V$ is located on the third terrace to the right of the Dniester, in Ukraine $\left(48^{\circ} 25^{\prime}\right.$ North latitude and 26 30' East longitude) and was found by de A. P. Cernîs in 1948 and archaeologically investigated, with some interruptions, from 1951 to 1964 (Noiret 2009).

\section{$8.2 \mid$ Ornaments description}

Level 8 , for which there is a C-14 date of $>24,600$ B.P. (LU-14), has revealed an ivory pendant which A. P. Cernîs (1987) interpreted as a small schematic female statuette, an assumption that Z. A. Abramova (1995) does not support. A perforated shell of the Cardium sp. has also been recovered from this level. In level 7, dated to between $25,280 \pm 210$ B.P. (GrA 9456) and 21,070 \pm 150 B.P. (GrA 9443), Z. A. Abramova (1995) mentions a Cardium shell and a Neritina one, another snail shell from an undetermined species as well as a perforated polar fox canine.

\section{9 | DISCUSSION}

The personal ornaments analysed come from occupations falling in between 26-27 ka uncal BP and $17 \mathrm{ka}$ uncal. BP. Unfortunately, aside from Poiana Ciresului, all the other
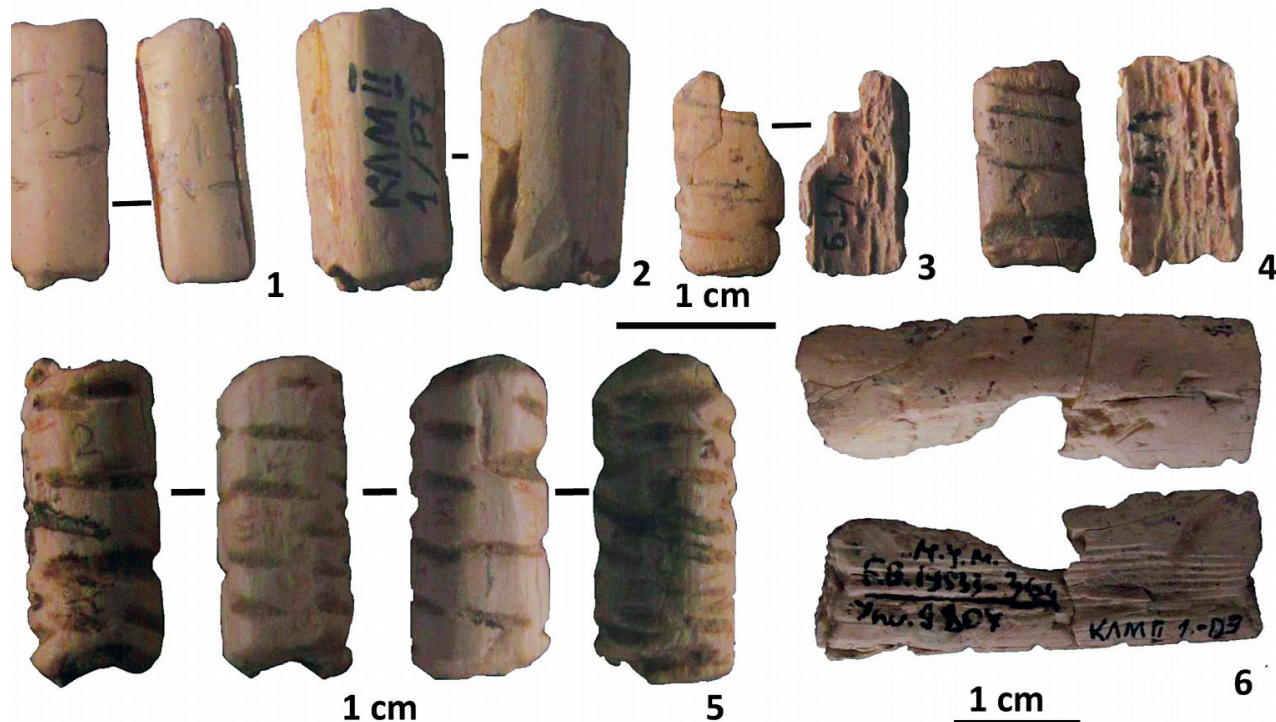

5

$1 \mathrm{~cm}$
6

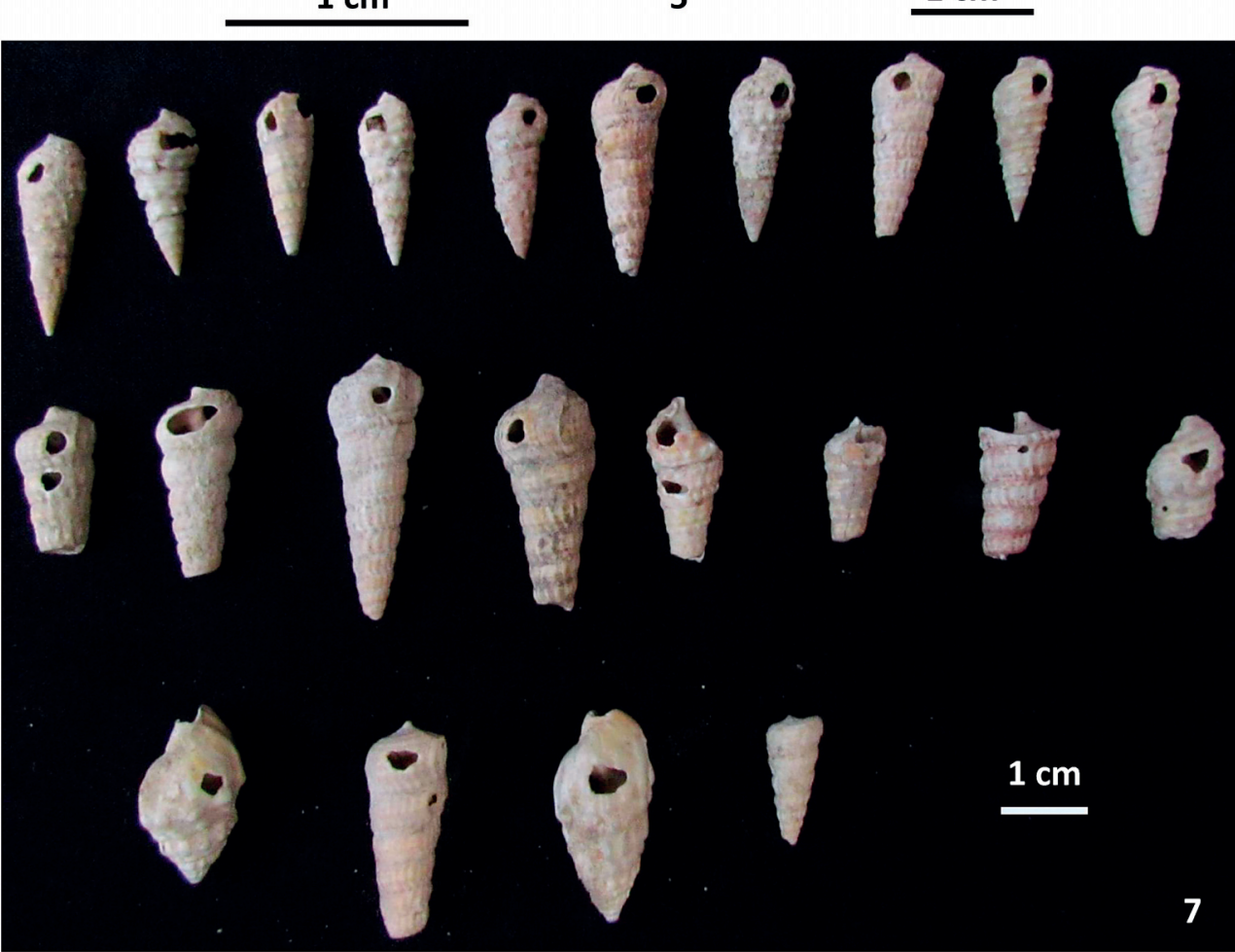

\section{FIGURE 10}

Various ornaments from the settlement of Climăuti. 1-5 - bone beads; 6 -rectangular bone, probably a fastener; 7-perforated shells of various fossil species.

Parures diverses du site de Climăuți : 1-5 - perles en os; 6 - os rectangulaire, probablement un bouton; 7 - coquilles perforées de différentes espèces fossiles. 
sites do not have a coherent chronological framework therefore a comparison between settlements is very difficult at this time. Located in the Eastern Carpathians, in an area with no significant natural barriers, having some occupations close chronologically, some categories of ornaments outlines different symbolic behaviour depending on the sites location. Others Upper Paleolithic ornaments are common, as are the perforated teeth of red deer, wolf or fox that is why we consider only certain ornaments, which individualize the communities.

The first occupation that is distinct from other settlements is represented by the Gravettian III layer from Poiana Cireșului (26-27 ka uncal. BP). The symbolic behavior is characterised by a unique association of perforated shells, not found in any other Gravettian settlement: Lithoglyphus naticoide and Lithoglyphus apertus as well as Homalopoma sanguineum. This discovery contributes to the identity of the Paleolithic community of Poiana Cireșului through their ornaments. The Homalopoma sanguineum is undeniably a Mediterranean species, which has never been mentioned in the Black Sea. The presence of a Mediterranean species at the Poiana Ciresului settlement located more than $900 \mathrm{~km}$ from the nearest source suggests the connection of communities here with the Mediterranean area as well as the possibility of a movement of populations from the south of the continent to the east of the Carpathians (Nitu et al. 2019)

There are also some peculiarities in the case of ornaments discovered in the first Gravettian layer at Poiana Cireșului (20 ka uncal. BP). For example, the importance of the siltite pendant found in the Gravettian I from Poiana CiresuluiPiatra Neamt, is given by its uniqueness in the context of the Eastern-European Upper Gravettian. Pendants such as those from Poiana Ciresului seem to be more common towards Eastern Europe and in the Asian part of Russia (Cârciumaru et al. 2016). The other two engraved stone pendant discovered at Mitoc-Malu Galben and Cosăuț belong to different chronological occupations that is why we cannot make no connection between them.

The perforated shells discovered at Poiana Ciresului in the Gravettian layer I, at Climăuți II, Cosăuti and Molodova V belong to fossil species, and this is a common characteristic with the eastern Carpathian settlements (even though the species is not determined for all gastropods from the sites in Republic of Moldova). If in Western and Central Europe there are many proofs regarding the existence of Dentalium beads in the Palaeolithic (Taborin 1993a), in Eastern Europe such finds are scarce, which makes the discovery from Poiana Ciresului a singular occurrence for the Gravettian in this part of Europe. In addition to the attestation of a few Dentalium beads recovered from a younger chronological level, at Borchtchevo 2 (LU 742: 13,210 2770 BP - GIN 88: $12,300 \pm 100 \mathrm{BP})$ (Abramova 1995), the Dentalium bead from Poiana Ciresului-Piatra Neamt is the oldest such evidence for the settlements inhabited during the Glacial Maximum.

In terms of the presence of fossil pendants, such as the belemnite from Duruitoarea veche, in this area, one may state they have been attested in Palaeolithic settlements as quite a rare phenomenon and an unusual occurrence. Belemnite fossils, which were not transformed into ornaments, have been mentioned at Pataud in the middle
Gravettian, in the Salpêtrien cave in the Solutrean etc. At Abri de Laugerie-Haute, also in the Solutrean, a belemnite with a "rainure" probably made for suspension is mentioned (Moncel et al. 2009). However, it was preserved in its initial form, whereas that from Duruitoarea Veche was used for working a blank, which was given a relatively flat rectangular shape. Instead, belemnite pendants had been made in the Russian Plain long before that from Duruitoarea Veche, the best known being those discovered in the Spitsynian of Kostenki 17 (Sinitsyn 2012).

Stones beads and amber objects are present only at Poiana Ciresului and Cosăuti. Bones beads are quite common for the majority of sites, except Poiana Ciresului. In the case of this type of ornaments, only at Climăuti II are discovered tubular bone beads, some of them being engraved.

The use of ivory for producing ornaments distinguish the settlements located on the left side of Prut river and on Dniester River in relation to Poiana Ciresului. However what singularize the Dniester sites is the presence of ivory bracelets. Z. Abramova (1995) distinguishes the tiaras from bracelets, in that the former are quite narrow polished ivory blades with holes at the ends while the latter refer to intact or fragmented ivory circles, which are often polished. If tiaras are much more numerous, with the most famous ones found at Kostenki, Mezin, Timonovka, Avdeevo and even in Siberia at Afontova Gora and Malta, the ivory bracelets have been acknowledged so far at Cosăuți, Climăuți and Mezin. Those in Siberia are especially made of schists or bituminous schists. This means that, according to finds so far, the Palaeolithic ivory bracelets are concentrated only in the area covered by the basins of the rivers Dniester and Dnieper, given that there is no natural obstacle east of the Carpathians that should limit the displacements of populations at that time over large areas and ivory was most certainly present everywhere.

\section{FUNDING}

M. Cârciumaru, E.-C. Nitu, O. Cîrstina, F. I. Lupu, M. Leu, and A. Nicolae acknowledge funding received for this project through the UEFISCDI Romania (Executive Agency for Higher Education, Research, Development and Innovation Funding) (project ID - PN III-P3-ID-PCE-2016-0614).

\section{REFERENCES}

ABRAMOVA A. Z. 1995 - L'art paléolithique d'Europe orientale et de Sibérie, L'Homme des Origines, Jérôme Millon, Grenoble, 367 p., 119 fig.

AVEZUELA B. 2010 - The personal ornaments mode from molluscs at the Middle-Late Magdalenian site of La Peña de Estebanvela (Segovia, Spain), Munibe SuplementoGahigaria, nr. 31, p. 48-56.

BARGE-MATHIEU H., TABORIN Y. 1991 - Fiche canines residuelles de cerfs, In: H. Barge-Mahieu, C. Beltier, H. CampsFabrer, P. Cattelain, L. Mons, N. Provenzano, Y. Taborin, Fiches typologiques de l'industrie osseuse préhistorique. Cahier IV: Objets de parure, Publication de l'Université de Provence, p. 1-6. 
BELDIMAN C. 2004 - Parures préhistoriques de Roumanie: pendeloques paléolithiques et épipaléolithiques (25.00010.000 B.P.), In: Otte M. (ed.), La Spiritualité, Actes de colloque de la commission 8 de l'UISPP (Paléolithique supérieur), Liège, 10-12 dècembre 2003, Liège, ERAUL, vol. 106, p. 55-69.

BORZIAC I. 1991 - Quelques données préalables sur l'habitat tardi-paléolithique pluristratifié de Cosseoutsy sur Dniestr moyen, In: V. Chirica, D. Monah (éd.), Le Paléolithique et Néolithique de la Roumanie en contexte européen, Biblioteca Archaeologica Iassiensis, IV, Iași, p. 56-71.

BORZIAC I. 1993 - Les chasseurs de renne de Kosoioutsy, site Paléolithique tardif à plusieurs niveaux sur le Dniestr Moyen (Rapport préliminaire), L'Anthropologie, T. 97, nr. 2/3, p. 331-336.

BORZIAC I. 1994 - Paleoliticul și Mezoliticul în spațiul dintre Nistru și Prut, Traco-Dacia, XV, 1-2, p. 19-40.

BORZIAC I. 1996 - The Late Palaeolithic in Moldova (19911995), In: Le Paléolithique supérieur européen. Bilan quinquennal 1991-1996, Liège, Université de Liège, ERAUL, 76, p. 33-40.

BORZIAC I., CHETRARU N. A. 1996 - La zone de Dniestr-Prut, In: V. Chirica, I. Borziac, N. A. Chetraru, Gisement du Paléolithique supérieur ancien entre Dniestr et Tisa, Helios, Iași, Biblioteca Archaeologica Iassiensis, V, p. 6-69.

BORZIAC I., CHIRICA C.-V. 1996 - Pièces de marne du Paléolithique supérieur de la vallée du Dniestr, Préhistoire européenne, 9, p. 393-401.

BORZIAC I., CHIRICA V., DAVID A. 2007 - L'Aurignacien moyen et tardif de l'espace Carpato-Dniestreen. Le gisement Climăuți II, Edition Pim, Iași, 225 p., 57 fig., 12 tab.

BORZIAC I., DAVID A., OBADĂ T. 1992 - Climăuți II. Un site de Paléolithique supérieur avec faune de mammouths dans la région du Dniestr, Anuarul Muzeului Național de Istorie a Moldovei, 1, p. 75-94 (en russe).

BORZIAC I., OTTE M. 1996 - Piese de artă paleolitică și de podoabă din stațiunea gravetiană pluristratigrafică Cosăuți (Nistrul mijlociu, Moldova), Lucrările Simpozionului de Arheologie, Târgoviște 23-25 noiembrie 1995, Târgoviște. 49-51.

BORZIAC I., OTTE M., NOIRET P. 1998 - Piese de artă paleolitică și de podoabă de la stațiunea paleolitică cu mai multe niveluri de locuire Cosăuți din zona Nistrului mijlociu, Revista Arheologică, Chișinău, 2, p. 5-27.

CÂRCIUMARU M., ANGHELINU M., LUCAS G., NIȚĂ L., STEGUWEIT L., MĂRGĂRIT M., FONTANA L., BRUGÉRE A., DUMITRAȘCU V., HAMBACH U., COSAC M., CÎRSTINA O., DUMITRU F. 2006 - Paleoliticul superior de la Poiana Cireşului (Piatra Neamţ). Noi rezultate, interpretări şi perspective, Muzeul Naţional de Istorie a României, Cercetări Arheologice, XIII, p. 11-37.

CÂRCIUMARU M., ANGHELINU M., NIȚĂ L., MĂRGĂRIT M., COSAC M., DUMITRU F., DUMITRAȘCU V., STEGUWEIT L., HAMBACH U., CÎRSTINA O. 2007 - Piatra Neamt, jud. Neamt, Punct Poiana Cireșului, Cronica cercetărilor arheologice din România, Campania 2006, A XLI-a Sesiune Națională de Rapoarte Arheologice, Tulcea, 29 mai-1 iunie 2006, p. 263-265.
CÂRCIUMARU M., ANGHELINU M., NITĂ L., MĂRGĂRIT M., DUMITRAȘCU V., DUMITRU F., COSAC M., CÎRSTINA O. 20072008 - A Cold Season Occupation during the LGM. The Early Epigravettian from Poiana Cireşului (judeţul Neamţ, NorthEastern, Romania), Acta Archaeologica Carpathica, Vol. XLIIXLIII, p. 27-58.

CÂRCIUMARU M., ANGHELINU M., STEGUWEIT L., NIȚĂ L., FONTANA L., BRUGÉRE A., HAMBACH U., MĂRGĂRIT M., DUMITRASCU V., COSAC M., DUMITRU F., CÎRSTINA O. 2010 The Pluristratified Upper Paleolithic Site From Poiana Cireşului, Piatra Neamţ. Recent Resultats and Future Prospects, In: C. Neugebauer-Maresch, L. Owen (Eds.), Aspects concerning the Middle and Eastern European Upper Paleolithic-Methods, Chronology, Technology and Subsistence, Symposium Wien, 9-11 November, 2005, Mitteilungen der Prähistorischen Kommission ÖAW, 2010, p. 209-219.

CÂRCIUMARU M., MĂRGĂRIT M., ANGHELINU M., NIȚĂ L., CÎRSTINA O., COSAC M., PLEȘA M., DUMITRU F. 2002-2003 - LeS découvertes d'art paléolithique de la valée de Bistriţa, dans le contexte de l'art mobilier paléolithique de Roumanie, Annales de l'Université Valahia Târgovişte, Section d'Archéologie et d'Histoire, Tome IV-V, p. 16-27;

CÂRCIUMARU M., NITUU E.-C. 2018 - Symbolic Behaviour and the Art on the Territory of Romania from the Middle Palaeolithic to the Mesolithic (55,000-7,500 B.P.), Editura Cetatea de Scaun, Târgoviște, 423 p., 104 fig., 12 tab.

CÂRCIUMARU M., NITU E.-C., CÎRSTINA O., GOUTAS N. 2016 The Engraved Stone Pendant from Poiana Cireşului-Piatra Neamţ, Romania. New Contributions to the Understanding of Symbolic Behavior in Gravettian, Archaeology, Ethnology \& Anthropology of Eurasia, 44/4, p. 35-45.

CÂRCIUMARU M., NIȚU E.-C., GOUTAS N., OTTE M., CÎRSTINA O., SAVA T., STRATICIUC M., MANEA M.-M., LUPU F. I., LEU M., NICOLAE A., NEAGU T. 2018 - Parures et objets d'art du Gravettien récent de Poiana Cireșului-Piatra Neamt, (Roumanie), L'Anthropologie, 122, p. 220-260.

CÂRCIUMARU M., NIȚU E.-C., ȚUȚUIANU-CÂRCIUMARU M. 2012 - L'art mobilier gravettien et épigravettien en Roumanie, In: Congrès IFRAO - L'art pléistocène dans le monde, 6-12 Septembre 2010, Ariège-Pyrénées, France, p. $240-241 / C D$, p. $1361-1377$.

CÂRCIUMARU M.,T,UTUUIANU-CÂRCIUMARU M. 2012 - The Oldest Snail (Lithoglyphus naticoides) necklace discovered in Romania in the Gravettian III stratum of Poiana Ciresului-Piatra Neamt [25.760 $\pm 160-27.321 \pm 234$ B.P. (31.969 ka)], Annales d'Université Valahia Târgovişte, Section d'Archéologie et d'Histoire, Tome XIV, Numéro 1, p. 19-42.

CERNÎS A. P. 1987 - The standard multilayered site Molodova V. Archeology, In: I. K. Ivanova, S. M. Meitzin (éds.), The Multylayered Paleolithic Site Molodova V. The Stone Age Men and Environment, Nauka, p. 7-93 (în rusă).

CHETRARU N. A. 1965a - Paleliticeskaia stojanka Ciutulești I, Izvestia Academii Nauc Moldavskoy SSR, 12, Chișinău, p. 53-61.

CHETRARU N. A. 1965b - Le site paléolithique dans la grotte située près du village de Staryé Duruitory, Protection de la nature moldave, III, p. 60-78 (en russe). 
CHETRARU N. A. 1970 - Un objet d'art paléolithique unique de la grotte de Brynzeny, Protection de la nature moldave, VIII, p. 133-138 (en russe).

CHETRARU N. A. 1989 - Un amulete du site du Paléolithique supérieur dans la grotte de Brynzeny I, In: Monuments de l'art le plus ancien sur le territoire de Moldavie, Chișinău, p. 5-10 (en russe).

CHIRICA V. 1982 - Amuleta-pandantiv de la Mitoc, jud. Botoşani. Notă preliminară, Studii şi cercetări de istorie veche şi arheologie, T. 33, nr. 2, p. 229-231.

CHIRICA V. 1989 - The Gravetian in the East of the Romanian Carpatians, Bibliotheca Archaeologica Iassiensis, III, Iași, 239 p., 88 fig.

CHIRICA V., BORZIAC I. 1995 - Les ivoires du sud-est de l'Europe: Bulgarie, Grèce, Yugoslavie et Roumanie jusqu'au Dniestr, In: J. Hahn, M. Menu, Y. Taborin, P. Walter, Fr. Wiedmann (Ed.), Le travail et l'usage au Paléolithique supérieur, Actes de la Table ronde de Ravello (29-31 mai 1992), Rome, Instituto poligrafico e zecca dello Stato, p. 199-210.

CHIRICA V., BORZIAC I. 2005 - Gisements du Paléolithique inférieur et moyen entre Dniestr et la Tisa, Editura Helios, Iași, $384 \mathrm{p}$

CHIRICA V., NOIRET P. 2007 - Mitoc-Malu Galben: industrie osseuse et témoins esthétiques, In: M. Otte, V. Chirica, P. Haesaerts (Sous la direction de), L'Aurignacien et Gravettien de Mitoc-Malu Galben (Moldavie Roumanie), ERAUL72, Liège, p. 143-144.

D'ERRICO F., HENSHILWOOD C., VANHAEREN M., VAN NIEKERK K. 2005 - Nassarius kraussianus shell beads from Blombos Cave: Evidence for symbolic behaviour in the Middle Stone Age, Journal of Human Evolution, 48, p. 3-24.

D'ERRICO F., JARDÓN-GINER P., SOLER-MAYOR B. 1993 Critères à base expérimentale pour l'étude des perforations naturelles et intentionnelles sur coquillages, In: P. C. Anderson, S. Beyries M. Otte, H. Plisson (Sous la direction de), Traces et fonction: les gestes retrouvés, Actes du colloque international de Liège, 8-10 décembre 1990, Éditions ERAUL, vol. 50, p. 243-254.

IONESI V. 2006 - Sarmaţianul dintre Valea Şiretului şi Valea Şomuzului Mare, Editura Universitătiii "Alexandru Ioan Cuza" Iași, 238 p.

KUHN L. S., STINER C. M. 2006 - Les parures au Paléolithique. Enjeux cognitif, démographiques et identitaires, Diogène 2 (214), p. 47-55.

MONCEL M.-H., CHIOTTI L., GAILLARD C., ONORATINI G., PLEURDENU D. 2009 - Emergence de la notion de précieux: objets insolites et extra-ordinaires au Paléolithique, In: M.H. Moncel, F. Fröhlich (Edité par), L'homme et précieux. Matières minérales précieuses, BAR International Series 1934, p. 13-37.
NIȚU E.-C., CÂRCIUMARU M., NICOLAE A., CÎRSTINA O., LUPU F. I., LEU M. 2019 - Mobility and social identity in the Mid Upper Paleolithic: New personal ornaments from Poiana Ciresului (Piatra Neamt, Romania), PLOS ONE, https://doi.org/10.1371/journal.pone.0214932.

NOIRET P. 2009 - Le Paléolithique supérieur de Moldavie, ERAUL 121, 609 p.

OTTE M., CHIRICA V., BELDIMAN C. 1995 - Sur les objets paléolithiques de parure et d'art en Roumanie: une pendeloque en os découverte a Mitoc, district de Botosani, Préhistoire Européenne, volume 7, p. 119-152.

PAILLET P. 2014 - L'Art des objets de la Préhistoire, Éditions Errance, Arles, 174 p., XL pl.

PAILLET P. 2018 - Qu'est-ce que l'art préhistorique ?, CNRS Éditions, Paris, 350 p., 222 fig.

SINISTYN A. A. 2012 - Figurative and decorative art of Kostenki: chronological and cultural differentiation, In: Clottes, J., (dir.), L'art pléistocène dans le monde, Actes du Congrès IFRAO,Tarascon-sur-Ariège, Bulletin de la Société Préhistorique Ariège-Pyrénées LXV-LXVI, CD, p. 1339-1359.

TABORIN Y. 1993a - La parure en coquillage au Paléolithique. Gallia préhistoire, Supplément XXIX, Editions CNRS, Paris, 538 p.

TABORIN Y. 1993b - Traces de façonnage et d'usage sur les coquillages perforés, In: P. C. Anderson, S. Beyries M. Otte, H. Plisson (sous la direction de), Traces et fonction: les gestes retrouvés, Actes du colloque international de Liège, 8-10 décembre 1990, Éditions ERAUL, vol. 50, p. 255-267.

TABORIN Y. 1996 - La parure préhistorique et la notion de territoire. In : L'art au Paléolithique et au Mésolithique, eds. Beltrán A, Vigliardi A (XIII International Congress of Prehistoric and Protohistoric Sciences, Forlí, Italia), p. 143-148.

VANHAEREN M. 2010 - Les fonctions de la parure au Paléolithique supérieur: de l'individu à l'unité culturelle. Éditions universitaires européennes, 355 p., 199 fig.

VANHAEREN M., D'ERRICO F. 2003 - Le mobilier funéraire de la Dame de Saint-Germain-la-Rivière (Gironde) et l'origine paléolithique des inégalités. Paleo, 15, p. 195-238. 